\title{
Source Attribution of Poly- and Perfluoroalkyl Substances (PFASs) in Surface Waters from Rhode Island and the New York Metropolitan Area
}

\section{Citation}

Zhang, Xianming, Rainer Lohmann, Clifton Dassuncao, Xindi C. Hu, Andrea K. Weber, Chad D. Vecitis, and Elsie M. Sunderland. 2016. "Source Attribution of Poly- and Perfluoroalkyl Substances (PFASs) in Surface Waters from Rhode Island and the New York Metropolitan Area." Environmental Science \& Technology Letters 3 (9) (September 13): 316-321. doi:10.1021/ acs.estlett.6b00255.

\section{Published Version}

doi:10.1021/acs.estlett.6b00255

\section{Permanent link}

http://nrs.harvard.edu/urn-3:HUL.InstRepos:30168293

\section{Terms of Use}

This article was downloaded from Harvard University's DASH repository, and is made available under the terms and conditions applicable to Open Access Policy Articles, as set forth at http:// nrs.harvard.edu/urn-3:HUL.InstRepos:dash.current.terms-of-use\#OAP

\section{Share Your Story}

The Harvard community has made this article openly available. Please share how this access benefits you. Submit a story. 
1 Source attribution of poly- and perfluoroalkyl substances (PFASs) in surface

2 waters from Rhode Island and the New York Metropolitan Area

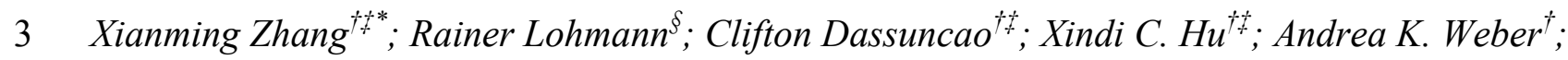

4 Chad D. Vecitis ${ }^{\dagger}$; Elsie M. Sunderland ${ }^{\dagger t}$

$5{ }^{\dagger}$ Harvard John A. Paulson School of Engineering and Applied Sciences, Harvard University,

6 Cambridge MA USA 02138

$7{ }^{\ddagger}$ Department of Environmental Health, Harvard T.H. Chan School of Public Health, Harvard

8 University, Boston MA USA 02115

$9{ }^{\S}$ Graduate School of Oceanography, University of Rhode Island

$10 *$ Corresponding author:

11 Xianming Zhang, E-mail: xmzhang@seas.harvard.edu; Tel: 617-495-2893 


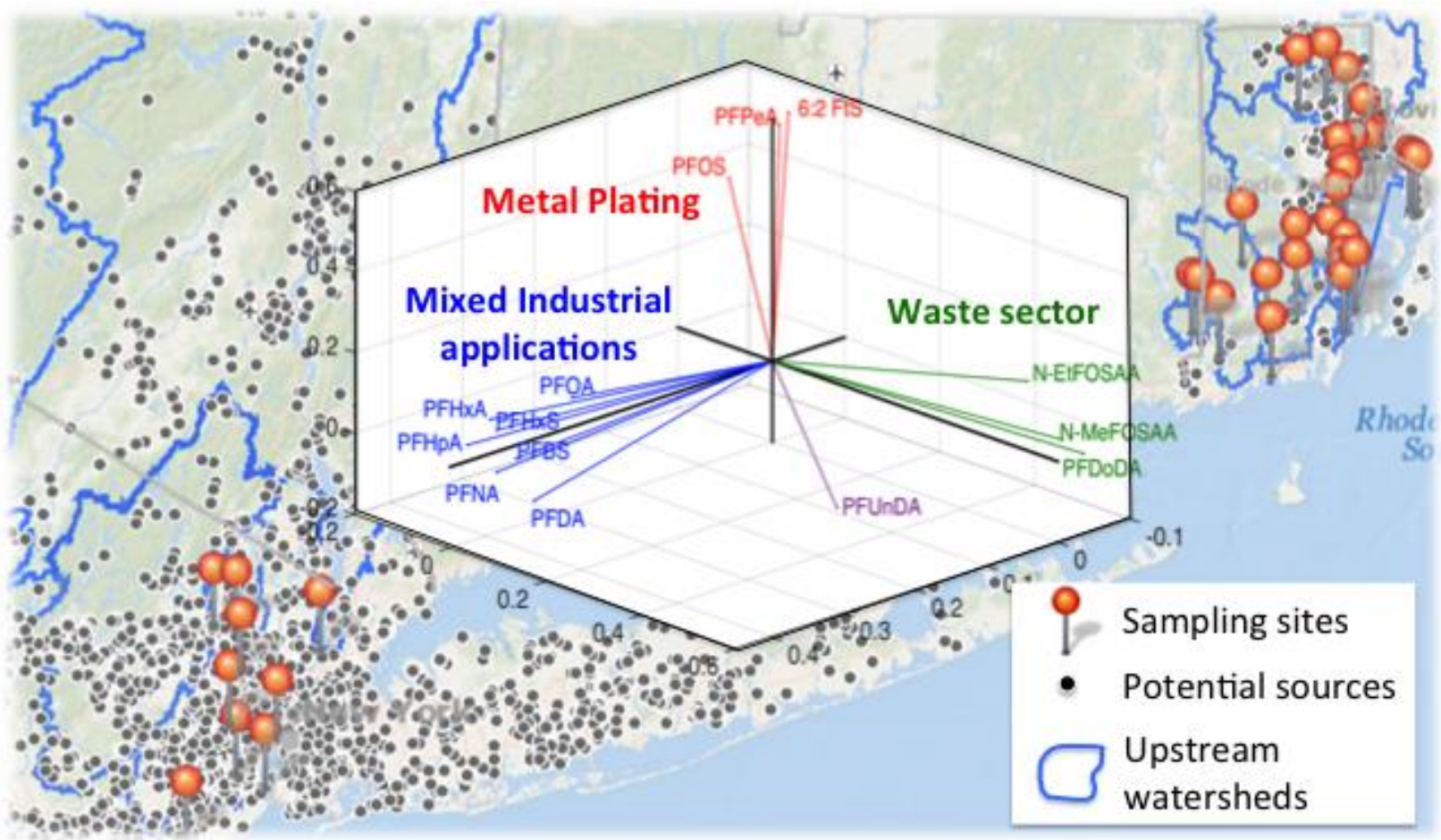




\section{Abstract}

15 Exposure to poly and perfluoroalkyl substances (PFASs) has been associated with adverse health

16 effects in humans and wildlife. Understanding pollution sources is essential for environmental

17 regulation but source attribution for PFASs has been confounded by limited information on

18 industrial releases and rapid changes in chemical production. Here we use principal component

19 analysis (PCA), hierarchical clustering, and geospatial analysis to understand source

20 contributions to 14 PFASs measured across 37 sites in the Northeastern United States in 2014.

21 PFASs are significantly elevated in urban areas compared to rural sites except for

22 perfluorobutane sulfonate (PFBS), N-methyl perfluorooctanesulfonamidoacetic acid (N-

23 MeFOSAA), perfluoroundecanate (PFUnDA) and perfluorododecanate (PFDoDA). The highest

24 PFAS concentrations across sites were for perfluorooctanate (PFOA, $56 \mathrm{ng} \mathrm{L}^{-1}$ ) and

25 perfluorohexane sulfonate (PFOS, $43 \mathrm{ng} \mathrm{L}^{-1}$ ) and PFOS levels are lower than earlier

26 measurements of U.S. surface waters. PCA and cluster analysis indicates three main statistical

27 groupings of PFASs. Geospatial analysis of watersheds reveals the first component/cluster

28 originates from a mixture of contemporary point sources such as airports and textile mills.

29 Atmospheric sources from the waste sector are consistent with the second component, and the

30 metal smelting industry plausibly explains the third component. We find this source-attribution

31 technique is effective for better understanding PFAS sources in urban areas. 


\section{Introduction}

Exposure to poly- and perfluoroalkyl substances (PFASs) has been associated with many

34 negative health outcomes including compromised immune function, metabolic disruption,

35 obesity, and altered liver function. ${ }^{1}$ PFASs in surface waters are an emerging concern for U.S.

36 public water supplies and long-chain compounds bioaccumulate in aquatic food webs, posing

37 health risks to seafood consumers. ${ }^{2-6}$ Production of PFASs and their precursors has shifted

38 dramatically over the last two decades toward shorter-chain and polyfluorinated species. ${ }^{7}$

39 Diverse point sources and atmospheric deposition of some PFASs confounds understanding of

40 the dominant contributors to contamination in the aquatic environment. Regulatory databases

41 such as the U.S. EPA's Facility Registry Survey (FRS) ${ }^{8}$ and the Toxic Release Inventory ${ }^{9}$

42 presently contain limited to no information on magnitudes of PFASs released to the environment.

43 Multivariate statistical analyses based on chemical composition profiles can be a

44 powerful tool for diagnosing contamination sources, as illustrated for many other organic

45 contaminants. ${ }^{10}$ Principal components analysis (PCA) provides information on

46 interrelationships among various chemicals and is useful for deriving common source

47 profiles. Two-way hierarchical clustering can be used as a confirmatory analysis of PCA by

48 generating a flexible number of subgroups of similar sites (those affected by a common

49 source type) without dictating the number of clusters a priori. Clustering of compounds

50 identifies chemicals that co-occur to form a unique signature. These techniques have not

51 been routinely applied to interpret PFAS contamination and show potential for interpreting

52 sources in surface water and seawater., ${ }^{4,11}$

53 Here we combine PCA and hierarchical clustering of PFAS profiles measured in surface

54 waters from 37 rivers, streams and estuaries in the Northeastern United States with geospatial 
55 analysis of potential sources. Few measurements are available for PFASs in U.S. surface waters

56 over the past five years and the importance of different sources is poorly understood. Source

57 regions for air pollution are commonly identified using back trajectories. ${ }^{12,13}$ We apply an

58 analogous approach for identifying sources of aquatic pollution based on hydrological

59 distances within a watershed. The main objective of this study is to identify major sources of

60 surface water PFAS contamination in diverse watersheds using information on chemical

61 composition and geospatial analytical tools that consider surface hydrology.

\section{Methods}

\section{Sample collection and analysis}

We collected surface water samples from rivers/creeks and estuaries at approximately 1

65 m depth at 28 sites in the state of Rhode Island (RI) in June, 2014 and 9 sites the New York

66 Metropolitan Area (NY/NJ) in October, 2014 (Figure 1). A complete description of sampling

67 sites is provided in the Supporting Information (SI Table S1). Precipitation and flow rates in

68 rivers tend to be higher in June, potentially resulting in enhanced dilution and a low bias for

69 some PFASs measured in RI rivers compared to NY/NJ.

70 Samples were stored in one-liter pre-rinsed polypropylene bottles at $-20{ }^{\circ} \mathrm{C}$ and thawed at

71 room temperature. Each sample was shaken vigorously for homogenization before subsampling

$72500 \mathrm{ml}$ for the analysis of 21 PFASs. Each unfiltered sample was spiked with $20 \mu \mathrm{L}$ of a $0.1 \mathrm{ng}$

$73 \mu \mathrm{L}^{-1}$ mass labeled PFAS mixture (Wellington; Guelph, Canada; individual compounds are listed

74 in Table S2) as internal standards for quantification. PFASs were extracted using an Oasis Wax

75 solid phase extraction (SPE) cartridge (6 mL, $150 \mathrm{mg}$ sorbent) following the method of Taniyasu

76 et. al. ${ }^{14}$ (see SI Section S1 for details). A nitrogen evaporator (ZIPVAP) was used to concentrate

77 the extract to $1 \mathrm{~mL}$ (methanol: water; $\mathrm{v}: \mathrm{v}=1: 1$ ). 
Sample detection for 21 native PFASs (Tables S2, S3) was performed using an Agilent

796460 LC-MS/MS equipped with an online-SPE system (Agilent 1290 Infinity Flex Cube) in

80 dynamic multiple reaction mode (sample chromatogram in Figure S1). At least one negative

81 control (field or procedural blank) and one positive control (spiked with $2 \mathrm{ng}$ of the 21 PFASs in

$82500 \mathrm{ml}$ water) were included in every extraction batch. Whole method recovery tested using the

83 positive controls was $70-120 \%$ for all but 4 PFASs that ranged from $60-70 \%$, which is

84 comparable to recoveries reported by previous studies. ${ }^{3,14,15}$. The 4 PFASs are perfluoropentanate

85 (PFPeA), perfluoroheptanate (PFHpA), N-methyl perfluorooctanesulfonamidoacetic acid

86 (MeFOSAA) and N-ethyl perfluorooctanesulfon-amidoacetic acid (EtFOSAA). Potential analyte

87 loss during sample preparation was corrected using internal standards spiked prior to sample

88 extraction. The limit of detection (LOD, Figure S2) was defined as equivalent to the blank plus

89 the concentration corresponding to a signal-to-noise ratio of three. Variability between duplicates

90 obtained at two sites was $<20 \%$. PFASs in five field blanks (HPLC grade water) prepared

91 following the sample preparation procedure were all below the LOD.

92 We quantified branched isomers for perfluorooctanate (PFOA), perfluorohexane

93 sulfonate (PFHxS), perfluorooctane sulfonate (PFOS), N-MeFOSAA and N-EtFOSAA using

94 calibration standards for the linear isomers, assuming the same instrumental response factor

95 (Table S3). Seven compounds namely perfluorododecane sulfonate (PFDS), 8:2 fluorotelomer

96 sulfonate (8:2 FTS), perfluorooctane sulfonamide (FOSA), and PFCAs with more than 12 carbon

97 atoms) were detected in less than half of samples and were excluded from additional statistical

98 analysis (see Table S2 for details). For the 14 PFASs that had detection frequencies of greater

99 than $60 \%$ (Table S2), we used the Robust Regression on Order Statistics approach for censored 
100 log-normally distributed environmental data described by Helsel ${ }^{16}$ to assign values to samples

101 with concentrations below the LOD.

\section{Statistical and spatial analysis}

103 We used principal components analysis (PCA) and hierarchical clustering to group sites

104 with statistically distinct PFAS composition profiles. PCA was performed using MATLAB's

105 Statistics Toolbox (MathWorks, Inc.) on normalized (z-score to remove the effect of

106 concentration difference at different sites) PFAS concentration data. The inverse of variances of

107 the data were used as variable weights and varimax rotation was applied to interpret the meaning

108 of extracted principal components. Hierarchical Cluster analysis was conducted using the hclust

109 function in the R statistical computing package (version 3.1.3).

110 We characterized the watershed for each freshwater sampling site using the U.S.

111 Geological Survey's (USGS) National Elevation Dataset (3 arc-second for site 15 and 16 and 1

112 arc-second for others) and the Hydrologic Tool in ArcGIS Pro 1.2 and ArcGIS online. Estuarine

113 sampling sites were excluded from the geospatial analysis due to the confounding influence of

114 tidal waters diluting potential source profiles. Population within each watershed was based on

115 ESRI's U.S. Demographic Database. ${ }^{17}$ We used the USGS's StreamStats database (version 4) ${ }^{18}$

116 to characterize water flow rates for each location and to compute mass flow (kg/yr) of PFASs at

117 each site and per-capita mass flows (kg/person/yr).

$118 \quad$ For all inland sites (non-estuarine), we acquired a list and geospatial data for plausible

119 PFAS sources from the US EPA Facility Registry Service (FRS) database on facilities and sites

120 subject to environmental regulation (see SI for the search criteria). ${ }^{8}$ These include airports,

121 facilities for metal plating/coating, printing, sewage treatment, waste management (including

122 landfills), and manufacturers of semiconductor, textile, paint/coating/adhesive, ink, paper, and 
123 petroleum products. A caveat of this analysis is that not all facilities included in the FRS

124 database necessarily release PFASs and the database may not comprehensively include all

125 possible sources.

126 Hydrological distances of point sources from each sampling site were computed using the

127 ArcGIS Trace Downstream tool. Within each watershed, we defined an indicator for the impact

128 of potential point sources as a function of distance from sampling locations by assuming

129 exponential decay in the source signature ${ }^{19}$ (i.e., impact $=1 / e^{d}$, where $d=$ hydrological distance,

$130 \mathrm{~km})$. This approach provides additional information on plausible sources that complements

131 multivariate statistical analysis but cannot be considered a quantitative estimate of contributions

132 to sampling locations since magnitudes of PFAS discharges are not available.

\section{Results and Discussion}

\section{Concentrations and spatial patterns}

135 Figure 1 shows the compound specific composition and concentrations of PFASs

136 measured in surface water samples as part of this work. Sampling sites in NY/NJ had much

137 greater population density in upstream watersheds (10-43x) compared to RI but the highest

138 concentrations of most PFASs were measured near the city of Providence, RI (Figure 1, Figure

139 S2). The range of measured PFAS concentrations reported here are comparable or lower than

140 U.S. surface waters from other regions collected between 2000-2009 (Table S4). ${ }^{2,20-24}$

141 All sites had detectable PFOA and PFNA and over 90\% contained detectable PFHxS,

142 PFOS, PFDA, and 6:2 FtS (Table S2, S3, Figure S2). The highest individual PFAS

143 concentration across sites was PFOA $\left(56 \mathrm{ng} \mathrm{L}^{-1}\right)$ at Site 31 (Passaic River, NJ). Highest

144 concentrations of PFHxS (43 ng L $\left.{ }^{-1}\right)$ and PFNA $\left(14 \mathrm{ng} \mathrm{L}^{-1}\right)$ were measured at Site 5 (Mill Cove,

145 RI). The maximum PFOS concentration $\left(27 \mathrm{ng} \mathrm{L}^{-1}\right)$ was measured at Site 2 (Woonasquatucket 
146 River, RI) within the City of Providence, RI. This is much lower than maximum levels reported

147 in earlier studies of US surface waters that range between 43-244 $\mathrm{ng} \mathrm{L}^{-1}$ (Table S4) and reflects

148 the continued decline in environmental PFOS burdens in North America following elimination of

149 production in $2002 .^{25,26}$

150

Measured PFAS concentrations in urban regions were significantly higher (Wilcoxin rank sum test, $p<0.017$ ) than rural sites for all compounds except PFBS, N-MeFOSAA, PFUnDA and PFDoDA (Figure S3). Sites 1-9 in RI and Sites 29-37 in NY/NJ are all urban areas, defined by population densities of greater than 1000 individuals per square mile $\left(2590 \mathrm{~km}^{2}\right)$, and population densities of greater than 500 individuals per square mile in surrounding census blocks. ${ }^{27} \mathrm{We}$ did not find a statistically significant correlation between total population in each upstream watershed and PFAS concentrations measured at each sampling site ( $p=0.12$ to 0.95 across compounds). We derived per-capita discharges (Figure S4) using a similar approach as Pistocchi and Loos. ${ }^{28}$ Highest median per-capita discharges ( $\mu$ g person ${ }^{-1}$ day $\left.^{-1}\right)$ across compounds, in decreasing order, were for PFOA (27), PFHxA (14), PFHpA (10), PFOS (9), PFHxS (7), and PFNA (5) (Figure S4). These are lower than previously reported in Europe ca. 2007 (e.g., PFOA: $82 \mu \mathrm{g}$ person $^{-1}$ day $^{-1}$, PFOS: $57 \mu \mathrm{g}$ person $^{-1}$ day $\left.^{-1}\right){ }^{28}$

\section{Source identification}

Both hierarchical clustering and PCA identified three distinct groupings of PFASs (Figure $2 \mathrm{a}, \mathrm{b}$ ). The first component/cluster explains $46 \%$ of variability in the PCA and includes two major end products of the fluorochemical manufacturing industry (PFOA, PFNA), and a mix of other compounds: PFBS, PFHxS, PFHxA, PFDA. Site 5 (Mill Cove, RI) contains the highest summed PFASs across all sites and is dominated by this mixture of PFASs. PCA results suggest Site 5 is statistically similar to the Pawcatuck River, RI sampling locations (Sites 20, 19) and the 
170 Passaic River, NJ (Site 31). However, these sites are grouped separately in the hierarchical 171 clustering analysis (Figure 2b), suggesting some differences in source contributions.

172 Geospatial analysis of the watersheds for Sites 5, 19, 20 and 31 reveals a mixture of

173 potential sources (Figure S5). For Site 5, the greatest source impact as a function of distance

174 within the watershed is from T.F. Green Airport, the largest public airport in Rhode Island. Prior

175 work indicates uses of AFFF in modern airports release diverse PFASs to downstream aquatic

176 environments, including the compounds identified as part of the first PCA/cluster. ${ }^{4,29-31}$ For Sites

17719 and 20, textile mills in the upstream watersheds have the highest impact as a function of

178 distance (Table S5). PFASs are used for water resistant coating in textiles and washing and

179 disposal of wastewater at textile mills provides a vector for their entry to the aquatic

180 environment. For Site 31, PCA scores suggest a mix of components 1-3 (Figure 2 c, d). This site

181 also clusters differently than Sites 19 and 20 (Figure 2b). The FCA database indicates the

182 watershed of Site 31 (Figure S5) contains diverse industrial sources that must account for this

183 profile including metal plating, printing, a landfill, petroleum and coal products manufacturing.

184 Overall, we conclude that the first PCA component and cluster of PFASs (PFOA, PFNA PFBS,

185 PFHxS, PFHxA, PFDA) represents a mixture of contemporary sources including airports and 186 textile mills.

187 The second component/cluster explains $19 \%$ of the variability in PFASs and includes two 188 long-chain PFASs (PFUnDA and PFDoDA) and two precursors to PFOS (MeFOSAA and 189 EtFOSAA) (Figure 2). PFUnDA and PFDoDA mainly originate from fluorotelomer alcohols or 190 other fluototelomer based products. ${ }^{32}$ Both N-MeFOSAA and N-EtFOSAA are intermediate 191 degradation products from the volatile parent compound $\mathrm{N}$-alkyl perfluorooctane 192 sulfamideoethanol (FOSE) with PFOS as the final degradation product. This profile is most 
193 pronounced at Site 3 along the Woonasquatucket River in RI and is also evident at Site 1

194 (Slack's Tributary, RI) and Site 6 (Buckeye Brook, RI). For Site 3, the largest source impact

195 based on distance is from a wastewater treatment plant $1 \mathrm{~km}$ upstream. No industrial facilities

196 exist upstream of Sites 1 and 6. Landfill/waste management facilities are located within $2 \mathrm{~km}$ of

197 all three sites but are not hydrologically connected to the sampling locations (Figure S5). Both

198 landfills and wastewater treatment plants are known atmospheric sources of fluorotelomer

199 alcohols and FOSE. ${ }^{33}$ Concentrations of N-MeFOSAA, PFUnDA and PFDoDA were not

200 spatially variable at most sites and only slightly elevated at Site 3, consistent with an atmospheric

201 input pathway. We thus infer that this component is most likely attributable to sources from the

202 waste sector.

203 The third component explains $15 \%$ of the variability in PFASs and includes PFPeA,

204 PFOS, and 6:2 FTS. This component is most pronounced at Site 2 along the Woonasquatucket

205 River, within the City of Providence, RI. GIS analysis of the watershed at this site reveals the

206 presence of 14 metal coating/plating industries upstream (Figure 2d, Table S5, Figure S5). PFOS

207 was historically used as a mist/fume control agent in metal plating, in surface coatings and as the

208 major component in AFFFs for fighting petroleum related fire. ${ }^{25,26,34}$ Some PFOS applications

209 such as metal plating have been replaced by less stable fluorotelomer based chemicals such as

$2106: 2 \mathrm{FtS},{ }^{35}$ which will eventually degrade into PFPeA and PFHxA (yields of $1.1 \%$ and $1.5 \%$ in

211 activated sludge) ${ }^{36}$ It is likely that PFHxA is not included in the cluster because other direct

212 sources can contribute one order of magnitude more PFHxA than PFPeA. ${ }^{37,38}$ We conclude that

213 the distinct PFAS profile at Site 2 is can be explained by the metal plating industry.

\section{Implications}


216 combined with data on hydrological proximity of potential sources are useful for identifying

217 sources of surface water contamination. We find aquatic transport pathways (hydrological

218 distance and river flow directions) are critical for source identification. This contrasts many other

219 persistent organic pollutants that are primarily transported atmospherically, allowing sources

220 within a radius surrounding the sampling sites to be linked to concentrations. ${ }^{39}$ We conclude that

221 the approach demonstrated here for RI and NY/NJ has potential for diagnosing PFAS source

222 contributions in urbanized regions with elevated concentrations and lacking specific information

223 on the magnitude of PFAS discharges from diverse industries. Background PFAS concentrations

224 at most rural sites in this study contain a mix of diverse source signatures that are not statistically

225 distinguishable using these methods. This analysis could be refined in future applications by

226 analyzing additional emerging short-chain PFASs and precursors to develop more unique

227 chemical signatures for specific industries (i.e., those contributing to the first component/cluster).

\section{Supporting Information}

229 Supporting Information Available: Details on analytical methods, data analyses, supporting

230 figures and tables. This material is available free of charge via the Internet at http://pubs.acs.org.

\section{ACKNOWLEDGMENTS}

232 We acknowledge financial support for this study from the Smith Family Foundation, the Harvard

233 John A. Paulson School of Engineering and Applied Sciences TomKat fund and the Harvard

234 NIEHS Center Grant (P30ES000002). X.Z. was partially supported by a Postdoctoral Fellowship

235 from the Natural Sciences and Engineering Research Council of Canada (PDF-437949-2013).

236 We thank Pete August (URI), Wenlu Zhao, Minggang Cai (Xiamen Univ.), Kirk Barrett 
237 (Manhattan College) for assistance with sample collection and GIS data. We thank Linda Green 238 and Elizabeth Herron, University of Rhode Island Watershed Watch program

239 (http://web.uri.edu/watershedwatch) leaders as well as the many URI Watershed Watch

240 volunteer water quality monitors who collected water samples. 


\section{References}

$242 \quad$ 1. Grandjean, P.; Andersen, E. W.; Budtz-Jorgensen, E.; Nielsen, F.; Molbak, K.; Weihe, P.; 243 Heilmann, C., Serum vaccine antibody concentrations in children exposed to perfluorinated 244 compounds. Jama-J Am Med Assoc 2012, 307, 391-397.

245 2. Post, G. B.; Louis, J. B.; Lippincott, R. L.; Procopio, N. A., Occurrence of Perfluorinated 246 Compounds in Raw Water from New Jersey Public Drinking Water Systems. Environ. Sci. 247 Technol. 2013, 47, 13266-13275.

248 3. Castiglioni, S.; Valsecchi, S.; Polesello, S.; Rusconi, M.; Melis, M.; Palmiotto, M.; 249 Manenti, A.; Davoli, E.; Zuccato, E., Sources and fate of perfluorinated compounds in the 250 aqueous environment and in drinking water of a highly urbanized and industrialized area in Italy. 251 J. Hazard. Mater. 2015, 282, 51-60.

2524 4. de Solla, S. R.; De Silva, A. O.; Letcher, R. J., Highly elevated levels of perfluorooctane sulfonate and other perfluorinated acids found in biota and surface water downstream of an international airport, Hamilton, Ontario, Canada. Environ. Int. 2012, 39, 19-26.

5. $\quad$ Hurley, S.; Houtz, E. F.; Goldberg, D.; Wang, M.; Park, J.; Nelson, D. O.; Reynolds, P.; Bernstein, L.; Anton-Culver, H.; Horn-Ross, P., Preliminary Associations between the Detection of Perfluoroalkyl Acids (PFAAs) in Drinking Water and Serum Concentrations in a Sample of California Women. Environ. Sci. Technol. Letters 2016.

6. Happonen, M.; Koivusalo, H.; Malve, O.; Perkola, N.; Juntunen, J.; Huttula, T., Contamination risk of raw drinking water caused by PFOA sources along a river reach in southwestern Finland. Sci. Total Environ. 2016, 541, 74-82.

7. Wang, Z. Y.; Cousins, I. T.; Scheringer, M.; Hungerbuhler, K., Fluorinated alternatives to long-chain perfluoroalkyl carboxylic acids (PFCAs), perfluoroalkane sulfonic acids (PFSAs) and their potential precursors. Environ. Int. 2013, 60, 242-248.

8. US EPA, Facility Registry Service (FRS). http://www.epa.gov/enviro/epa-frs-facilitiesstate-single-file-csv-download (accessed Nov 2015).

9. U.S. EPA, Toxics Release Inventory (TRI) Program. https://http://www.epa.gov/toxicsrelease-inventory-tri-program (accessed May 2016).

10. Johnson, G. W.; Ehrlich, R.; Full, W.; Ramos, S., Principal components analysis and receptor models in environmental forensics. Academic Press, San Diego, CA: 2002.

11. Benskin, J. P.; Ahrens, L.; Muir, D. C. G.; Scott, B. F.; Spencer, C.; Rosenberg, B.; Tomy, G.; Kylin, H.; Lohmann, R.; Martin, J. W., Manufacturing Origin of Perfluorooctanoate (PFOA) in Atlantic and Canadian Arctic Seawater. Environ. Sci. Technol. 2012, 46, 677-685. 12. Zhang, X.; Meyer, T.; Muir, D. C.; Teixeira, C.; Wang, X.; Wania, F., Atmospheric deposition of current use pesticides in the Arctic: snow core records from the Devon Island Ice Cap, Nunavut, Canada. Environ Sci Process Impacts 2013, 15, 2304-11.

13. Westgate, J. N.; Wania, F., On the construction, comparison, and variability of airsheds for interpreting semivolatile organic compounds in passively sampled air. Environ. Sci. Technol. 2011, 45, 8850-7.

14. Taniyasu, S.; Kannan, K.; So, M. K.; Gulkowska, A.; Sinclair, E.; Okazawa, T.; Yamashita, N., Analysis of fluorotelomer alcohols, fluorotelorner acids, and short- and longchain perfluorinated acids in water and biota. J. Chromatogr. A 2005, 1093, 89-97.

15. D'eon, J. C.; Crozier, P. W.; Furdui, V. I.; Reiner, E. J.; Libelo, E. L.; Mabury, S. A., Perfluorinated Phosphonic Acids in Canadian Surface Waters and Wastewater Treatment Plant Effluent: Discovery of a New Class of Perfluorinated Acids. Environ. Toxicol. Chem. 2009, 28, 
287 16. Helsel, D. R., Nondetects and data analysis : statistics for censored environmental data.

288 Wiley-Interscience: Hoboken, N.J., 2005; p xv, 250 p. 17. ESRI Demographics (2012) Population density in the United States.

http://www.esri.com/data/esri_data (accessed May 2016).

18. U.S. Geological Survey StreamStats (version 4). http://ssdev.cr.usgs.gov/streamstats/ (accessed May 2016).

19. Sakurai, T.; Serizawa, S.; Kobayashi, J.; Kodama, K.; Lee, J. H.; Maki, H.; Zushi, Y.; Sevilla-Nastor, J. B.; Imaizumi, Y.; Suzuki, N.; Horiguchi, T.; Shiraishi, H., Temporal trends for inflow of perfluorooctanesulfonate (PFOS) and perfluorooctanoate (PFOA) to Tokyo Bay, Japan, estimated by a receptor-oriented approach. Sci. Total Environ. 2016, 539, 277-85.

20. Hansen, K. J.; Johnson, H. O.; Eldridge, J. S.; Butenhoff, J. L.; Dick, L. A., Quantitative characterization of trace levels of PFOS and PFOA in the Tennessee River. Environ. Sci. Technol. 2002, 36, 1681-1685.

21. Nakayama, S.; Strynar, M. J.; Helfant, L.; Egeghy, P.; Ye, X. B.; Lindstrom, A. B., Perfluorinated compounds in the Cape Fear Drainage Basin in North Carolina. Environ. Sci. Technol. 2007, 41, 5271-5276.

22. Konwick, B. J.; Tomy, G. T.; Ismail, N.; Peterson, J. T.; Fauver, R. J.; Higginbotham, D.; Fisk, A. T., Concentrations and patterns of perfluoroalkyl acids in Georgia, USA surface waters near and distant to a major use source. Environ. Toxicol. Chem. 2008, 27, 2011-2018. 23. Nakayama, S. F.; Strynar, M. J.; Reiner, J. L.; Delinsky, A. D.; Lindstrom, A. B., Determination of Perfluorinated Compounds in the Upper Mississippi River Basin. Environ. Sci. Technol. 2010, 44, 4103-4109.

24. Lasier, P. J.; Washington, J. W.; Hassan, S. M.; Jenkins, T. M., Perfluorinated chemicals in surface waters and sediments from northwest Georgia, USA, and their bioaccumulation in Lumbriculus variegatus. Environ. Toxicol. Chem. 2011, 30, 2194-201.

25. Paul, A. G.; Jones, K. C.; Sweetman, A. J., A first global production, emission, and environmental inventory for perfluorooctane sulfonate. Environ. Sci. Technol. 2009, 43, 386392.

26. Armitage, J. M.; Schenker, U.; Scheringer, M.; Martin, J. W.; MacLeod, M.; Cousins, I. T., Modeling the Global Fate and Transport of Perfluorooctane Sulfonate (PFOS) and Precursor Compounds in Relation to Temporal Trends in Wildlife Exposure. Environ. Sci. Technol. 2009, 43, 9274-9280.

27. US Census Bureau (1995) Urban And Rural Definitions. http://www.census.gov/population/censusdata/urdef.txt (accessed June 2016).

28. Pistocchi, A.; Loos, R., A Map of European Emissions and Concentrations of PFOS and PFOA. Environ. Sci. Technol. 2009, 43, 9237-9244.

29. Ahrens, L.; Norström, K.; Viktor, T.; Cousins, A. P.; Josefsson, S., Stockholm Arlanda Airport as a source of per- and polyfluoroalkyl substances to water, sediment and fish. Chemosphere 2015, 129, 33-38.

30. Awad, E.; Zhang, X. M.; Bhavsar, S. P.; Petro, S.; Crozier, P. W.; Reiner, E. J.; Fletcher, R.; Tittemier, S. A.; Braekevelt, E., Long-Term Environmental Fate of Perfluorinated Compounds after Accidental Release at Toronto Airport. Environ. Sci. Technol. 2011, 45, 80818089 .

31. Filipovic, M.; Woldegiorgis, A.; Norstrom, K.; Bibi, M.; Lindberg, M.; Osteras, A. H., Historical usage of aqueous film forming foam: A case study of the widespread distribution of 
perfluoroalkyl acids from a military airport to groundwater, lakes, soils and fish. Chemosphere 333 2015, 129, 39-45.

334 32. Government of Canada, Chemical Substances: Long-Chain (C9-C20)

335 Perfluorocarboxylic Acids (PFCAs), Their Salts, and Their Precursors

336 http://www.chemicalsubstanceschimiques.gc.ca/challenge-defi/summary-sommaire/pfcaps-

337 apfcsp-eng.php (accessed Nov 2015).

338 33. Ahrens, L.; Shoeib, M.; Harner, T.; Lee, S. C.; Guo, R.; Reiner, E. J., Wastewater

339 Treatment Plant and Landfills as Sources of Polyfluoroalkyl Compounds to the Atmosphere.

340 Environ. Sci. Technol. 2011, 45, 8098-8105.

34134 . Moody, C. A.; Field, J. A., Perfluorinated surfactants and the environmental implications

342 of their use in fire-fighting foams. Environ. Sci. Technol. 2000, 34, 3864-3870.

343 35. Persistent Organic Pollutants Review Committee of UNEP (2012) Technical paper on the

344 identification and assessment of alternatives to the use of perfluorooctane sulfonic acid, its salts,

345 perfluorooctane sulfonyl fluoride and their related chemicals in open applications

346 (UNEP/POPS/POPRC.8/INF/17/Rev.1).

347 36. Wang, N.; Szostek, B.; Buck, R. C.; Folsom, P. W.; Sulecki, L. M.; Gannon, J. T., 8-2

348 Fluorotelomer alcohol aerobic soil biodegradation: Pathways, metabolites, and metabolite yields.

349 Chemosphere 2009, 75, 1089-1096.

$350 \quad 37 . \quad$ Dauchy, X.; Boiteux, V.; Rosin, C.; Munoz, J. F., Relationship Between Industrial

351 Discharges and Contamination of Raw Water Resources by Perfluorinated Compounds: Part II:

352 Case Study of a Fluorotelomer Polymer Manufacturing Plant. Bull. Environ. Contam. Toxicol.

353 2012, 89, 531-536.

$35438 . \quad$ Butenhoff, J. L.; Kennedy, G. L., Jr.; Frame, S. R.; O'Connor, J. C.; York, R. G., The

355 reproductive toxicology of ammonium perfluorooctanoate (APFO) in the rat. Toxicology 2004, 356 196, 95-116.

357 39. Khairy, M.; Muir, D.; Teixeira, C.; Lohmann, R., Spatial Distribution, Air-Water

358 Fugacity Ratios and Source Apportionment of Polychlorinated Biphenyls in the Lower Great

359 Lakes Basin. Environ. Sci. Technol. 2015, 49, 13787-97. 


\section{$361 \quad$ Figure Captions}

362 Figure 1. Concentrations of PFASs measured in surface waters from Rhode Island and the New

363 York Metropolitan Area. Full names of individual compounds are listed in Table S2. N-

364 MeFOSAA and N-EtFOSAA are not shown but were detected in $\sim 70 \%$ of the samples at

365 concentrations $<1 \mathrm{ng} / \mathrm{L}$.

366

367 Figure 2. Multivariate statistical analysis of surface water data. Panel (A) shows loadings of

368 principal components analysis (PCA) and Panels (C) and (D) show score plots for three

369 components across sampling sites. Panel (B) compares PCA results to hierarchical clustering of

370 compounds and sites. Sites with statistically distinct PFAS profiles are indicated on plots (C)

371 and (D) and highlighted on the hierarchical clustering diagram. The three principal components

372 together explain $80 \%$ of the variance in PFAS composition. 
Figure 1

Per-and poly-fluoroalkane sulfonates

$10 \mathrm{ng} / \mathrm{L}$
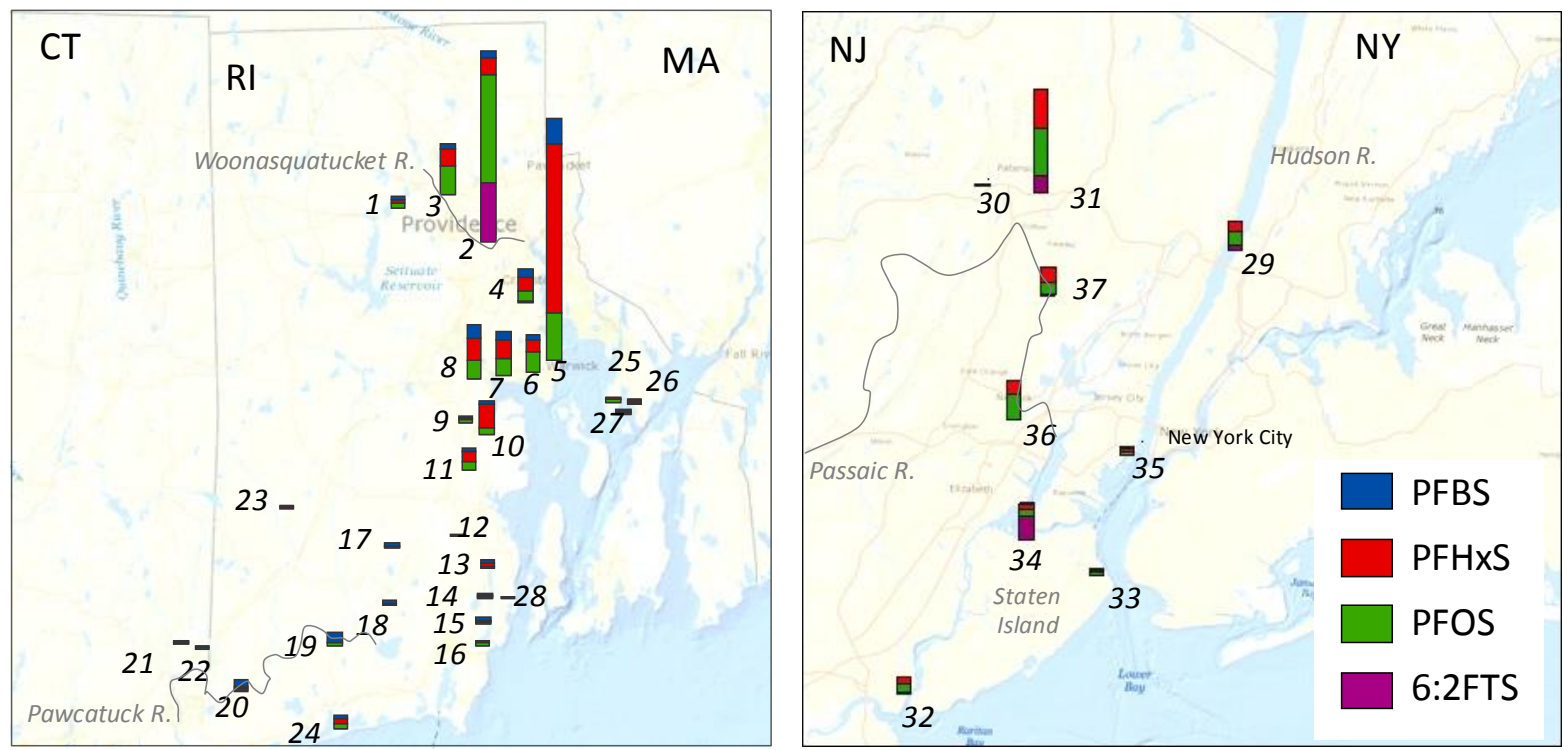

Perfluorocarboxylates \30 ng/L
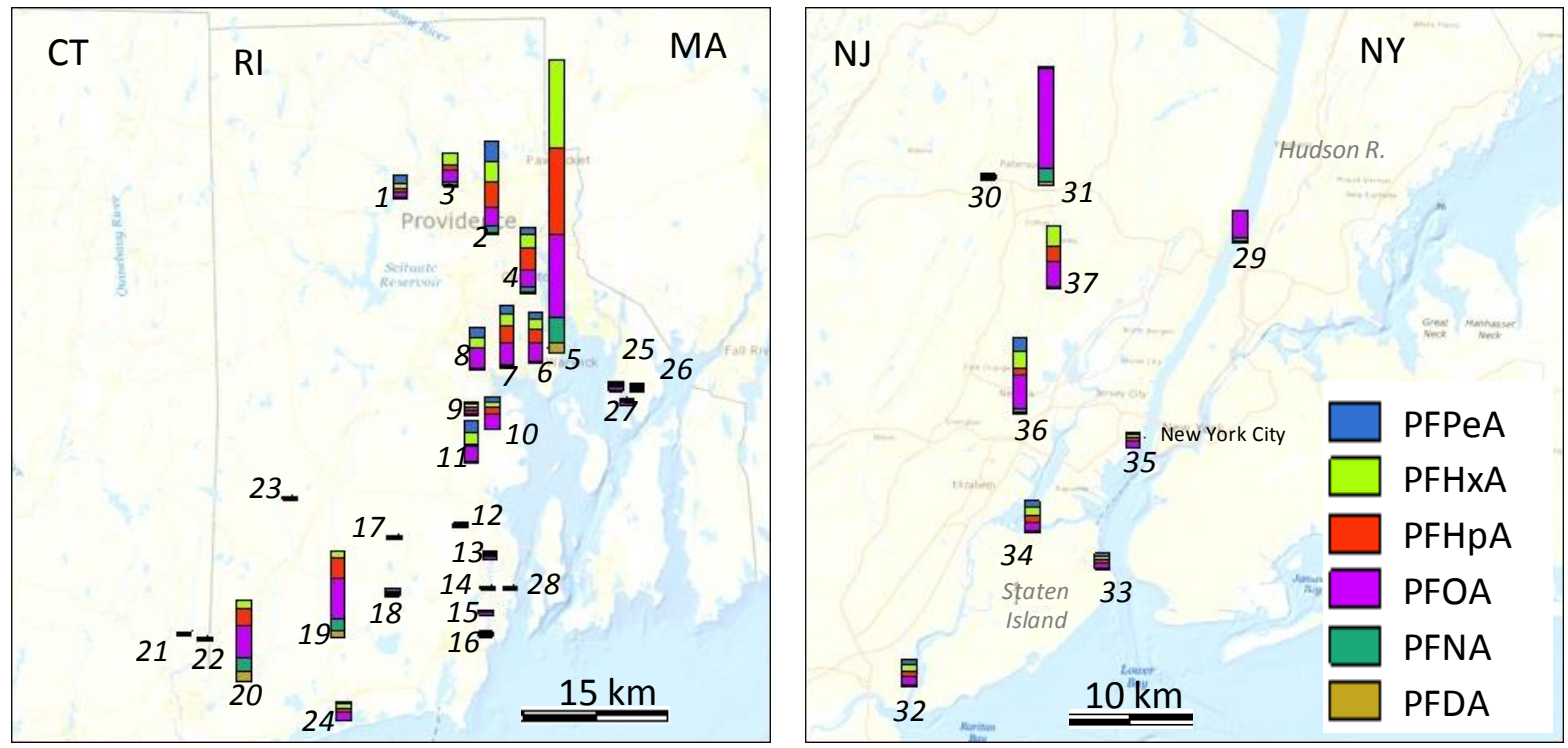
Figure 2

(A)

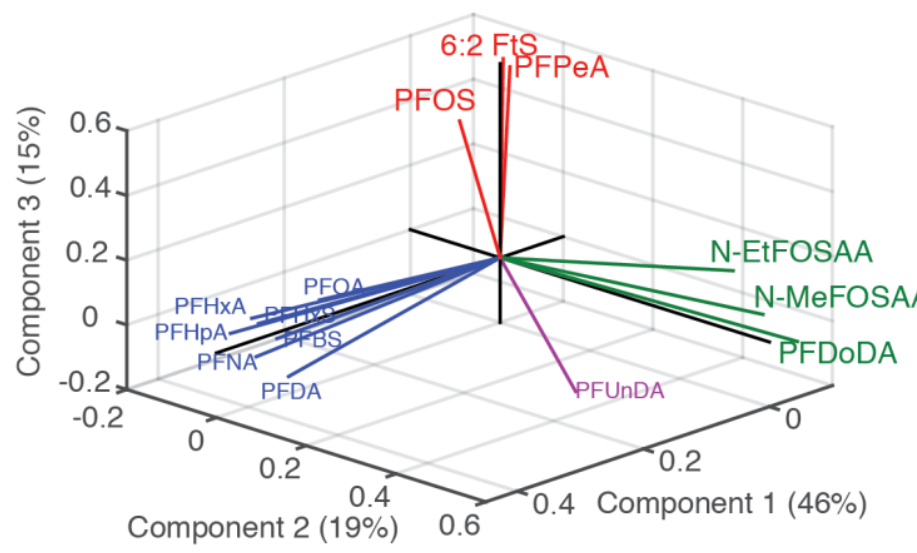

(C)

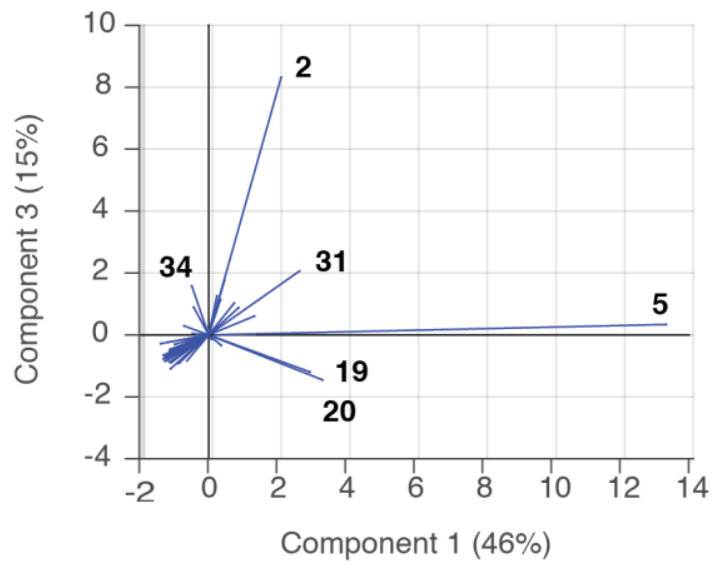

(B)
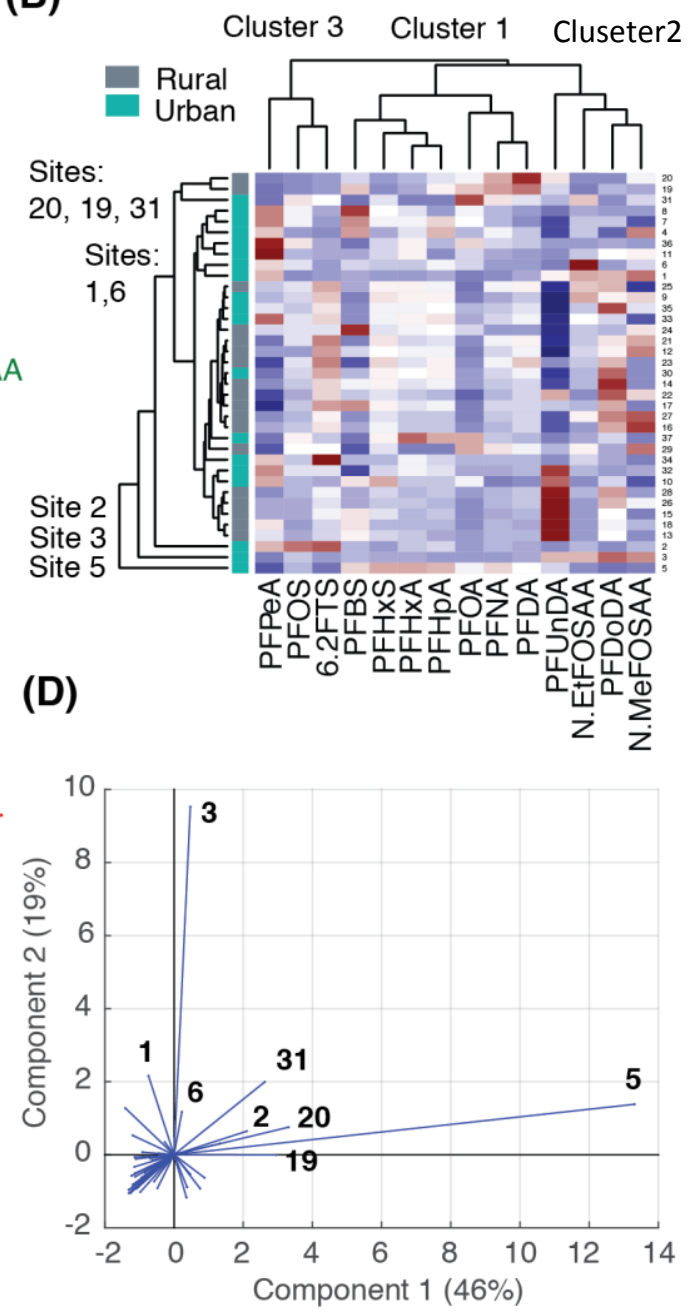


\section{Supporting Information}

2 Concentrations and source attribution of poly- and perfluoroalkyl substances (PFASs) in surface

3 waters from the Northeastern U.S.

4 Xianming Zhang ${ }^{\dagger \neq}$; Rainer Lohmann $^{\S}$; Clifton Dassuncao ${ }^{\dagger *}$; Xindi C. Hu ${ }^{\dagger \neq}$; Andrea Weber ${ }^{\dagger}$,

5 Chad D. Vecitis $^{\dagger}$, Elsie M. Sunderland ${ }^{\dagger *}$

$6{ }^{\dagger}$ Harvard John A. Paulson School of Engineering and Applied Sciences, Harvard University,

$7 \quad$ Cambridge MA USA 02138

$8{ }^{\ddagger}$ Department of Environmental Health, Harvard T.H. Chan School of Public Health, Harvard

9 University, Boston MA USA 02115

$10 \S$ Graduate School of Oceanography, University of Rhode Island

11 Number of pages: 20

12 Number of tables: 5

13 Number of figures: 5 


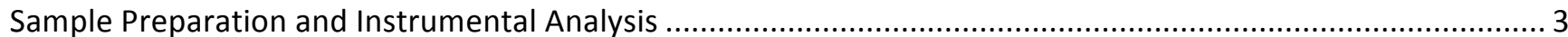

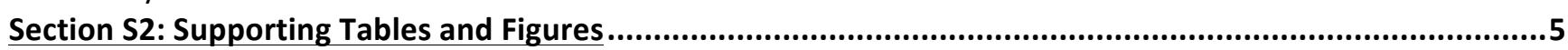

Table S1. Surface water sampling dates, site locations and description................................................... 5

Table S2. Full names and acronyms of PFASs measured in surface waters, limits of detection (LOD), concentration ranges measured across sites, and percent of sites with detection. PFASs measured in $>60 \%$ of samples analyzed in this study are highlighted in bold.

Figure S1. Chromatograms of PFASs in a sample analyzed using an Agilent 6460 LC-MS/MS equipped with an online-SPE system (Agilent 1290 Infinity Flex Cube) in dynamic multiple reaction mode.

Table S3a. Concentrations ( $\mathrm{pg} / \mathrm{L}$ ) of poly- and perfluoroalkyl substances with detection frequency greater than $60 \%$.

Table S3b. Concentrations ( $\mathrm{pg} / \mathrm{L}$ ) of poly- and perfluoroalkyl substances with detection frequency greater than $60 \%$.

Table S3c. Concentrations (pg/L) of branched isomers* of poly- and perfluoroalkyl substances ..................... 12

Table S4. PFAS concentrations measured in U.S. surface waters in this study and previous work. ................... 13

Figure S2. Concentrations of 14-PFASs measured in 37 rivers and estuaries in Rhode Island (RI) and the New York Metropolitan area (NY/NJ). PFASs with branched isomers were quantified using calibration standards of the linear isomers by assuming same response factors between isomers. The limit of detection (LOD) for each compound is shown as a red bar. Those below detection are assigned values based on the robust ROS (Regression on Order Statistics) approach for censored log-normally distributed environmental data as described by Helsel. ${ }^{2}$.

Figure S3. Significance levels for Wilcoxon rank sum tests comparing PFAS concentrations (a) between urban sites (RI sites 1-11 and NY/NJ sites 29-37) and rural sites 12-28 (b) RI sites 1-11 and NY/NJ sites 2937. Red line denotes $p=0.05$, which we use to indicate statistical significance.

Figure S4. Per-capita release of PFAS ( $\mu \mathrm{g} /$ person/d) estimated based on measured PFAS concentrations, water flow rate and upstream population at each sampling site.

Figure S5. Maps showing sampling sites with distinct PFAS composition profiles, the upstream watersheds and the potential source contributions.

Table S5. Impact factors for potential PFAS sources in watersheds upstream of the non-estuarine sampling sites. 


\section{Sample Preparation and Instrumental Analysis}

PFASs were extracted from water samples using Oasis Wax (6 ml, $150 \mathrm{mg}$ sorbent) solid phase

53 extraction (SPE) cartridges following the method of Taniyasu et al. ${ }^{1}$ Each $500 \mathrm{ml}$ water sample was

54 passed through a preconditioned Oasis Wax (6 ml, $150 \mathrm{mg}$ sorbent) weak ion exchange SPE cartridge

55 mounted on a vacuum manifold at a flow rate of $\sim 1$ drop/s. Target analytes were eluted off the

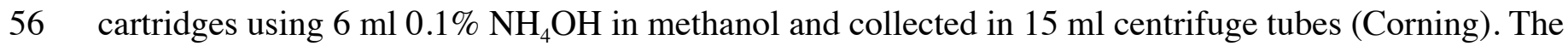

57 extracts were concentrated to $0.5 \mathrm{ml}$ under a gentle stream of high purity nitrogen (5.0 grade),

58 centrifuged at $5000 \mathrm{rpm}$ for 10 minutes, and transferred $1.5 \mathrm{ml}$ polypropylene auto-sampler vials

59 (Microsolv). Before instrumental analysis, $0.5 \mathrm{ml}$ water was added to each sample and vortex mixed. $(4.6 \times 12.5 \mathrm{~mm} ; 5 \mu \mathrm{m})$ online SPE column with $0.85 \mathrm{ml} 0.1 \%(\mathrm{v}: \mathrm{v})$ formic acid at a flow rate of 1 $\mathrm{ml} / \mathrm{min}$. Following sample loading, the SPE were eluted and load the analytes to an Agilent Poroshell

63120 EC-C18 $(3.0 \times 50 \mathrm{~mm} ; 2.7 \mu \mathrm{m})$ reverse phase HPLC column. Methanol and water containing $2 \mathrm{mM}$

64 ammonium acetate were used as mobile phases (flow rate: $0.5 \mathrm{ml} / \mathrm{min}$ ). Starting from $3 \%$ methanol,

65 the elution gradient was linearly increased to $61 \%$ in 7 minutes, held for 1 minute, then linearly

66 increased to $100 \%$ methanol in $3 \mathrm{~min}$, and was kept until the end of the sample run (14 $\mathrm{min}$ ).

The tandem mass spectrometer equipped with an electrospray ionization source was operated in negative ion mode. Dynamic multiple reaction monitoring (dMRM) mode was used for data acquisition in order to increase sensitivity. The collision gas was 5.0 grade $\mathrm{N}_{2}$. Optimized MS parameters are as follows: source temperature, $300{ }^{\circ} \mathrm{C}$; capillary voltage, $-3.8 \mathrm{kV}$; nitrogen nebulizer gas, 45 psi and $13 \mathrm{~L} / \mathrm{min}$. Methanol was injected and passed through the system to eliminate any

72 potential carry-over after every sample (or calibration standard). 
74 the C-18 reverse phase HPLC column, which would result in a low accuracy. ${ }^{2}$ A different analytical

75 method (e.g., using a normal phase HPLC column) that can accurately measure those shorter chain

76 PFASs is needed to detect these compounds and represents a limitation of the present analysis.

\section{Data analysis}

78 Helsel $^{2}$ suggests statistical inference bias may occur for data with detection frequencies of less

79 than $30 \%$. PFASs with detection frequencies of $60-70 \%$ are included here because they are important

80 for source identification. We tested results of principal component analysis with and without PFASs

81 with low detection frequencies (60-65\%: PFPeA, PFHpA, PFDoDA) and find no significant changes in

82 PCA scores (Wilcoxson signed rank tests $(p=0.06-0.5)$ and clustering included in the main results of

83 this work.

Potential industrial PFAS point sources were retrieved from the US EPA Facility Registry

85 Service (FRS) database and used in the geospatial analysis conducted as part of this research. Filtering

86 of the database was based North American Industry Classification System (NAICS) codes. Facilities

87 and their coordinates were retrieved based on the following NAICS codes: Sewage treatment facilities

88 (22132); textile mills (313); paper manufacturing (322); printing and related support activities (323);

89 petroleum and coal products manufacturing (324); paint, coating, and adhesive manufacturing (3255);

90 printing ink manufacturing (32591); metal coating, engraving, heat treating and allied activities (3328);

91 semiconductor manufacturing (3344); airport operation (48811); waste management and remediation

$92(562)$




\section{Section S2: Supporting Tables and Figures}

94 Table S1. Surface water sampling dates, site locations and description.

\begin{tabular}{|c|c|c|c|c|c|c|c|}
\hline 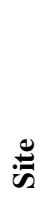 & .0气 & 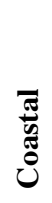 & 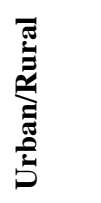 & 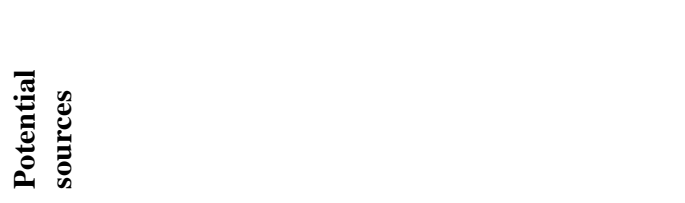 & 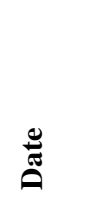 & 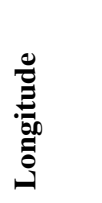 & 蔨 \\
\hline 1 & $\begin{array}{l}\text { Slack's } \\
\text { Tributary }\end{array}$ & $\mathrm{N}$ & Urban & $\begin{array}{l}\text { No hydrologically connected point sources; a landfill } \\
\text { is located } 1.9 \mathrm{~km} \text { to the north }\end{array}$ & $\begin{array}{l}06 / 19 / \\
2014\end{array}$ & -71.55 & 41.85 \\
\hline 2 & $\begin{array}{l}\text { Woonasqua- } \\
\text { tucket River }\end{array}$ & $\mathrm{N}$ & Urban & Metal coating/plating & $\begin{array}{l}06 / 19 / \\
2014\end{array}$ & -71.44 & 41.82 \\
\hline 3 & $\begin{array}{l}\text { Woonasqua- } \\
\text { tucket River } \\
\text { (Greystone } \\
\text { pond) }\end{array}$ & $\mathrm{N}$ & Urban & Wastewater treatment plant, printing activity & $\begin{array}{l}06 / 19 / \\
2014\end{array}$ & -71.49 & 41.87 \\
\hline 4 & $\begin{array}{l}\text { Pawtuxet } \\
\text { River }\end{array}$ & $\mathrm{N}$ & Urban & Metal coating/plating, semiconductor manufacturing & $\begin{array}{l}06 / 19 / \\
2014\end{array}$ & -71.40 & 41.77 \\
\hline 5 & $\begin{array}{l}\text { Brook at } \\
\text { Mill Cove }\end{array}$ & $\mathrm{N}$ & Urban & T.F. Green State Airport 5km upstream & $\begin{array}{l}06 / 19 / \\
2014\end{array}$ & -71.38 & 41.71 \\
\hline 6 & $\begin{array}{l}\text { Buckeye } \\
\text { Brook }\end{array}$ & $\mathrm{N}$ & Urban & $\begin{array}{l}\text { No hydrologically connected point sources; a landfill } \\
\text { is located } 2.3 \mathrm{~km} \text { to the west }\end{array}$ & $\begin{array}{l}06 / 19 / \\
2014\end{array}$ & -71.39 & 41.70 \\
\hline 7 & $\begin{array}{l}\text { Southern } \\
\text { Creek }\end{array}$ & $\mathrm{N}$ & Urban & No hydrologically connected point sources & $\begin{array}{l}06 / 19 / \\
2014\end{array}$ & -71.42 & 41.70 \\
\hline 8 & Mill Brook & $\mathrm{N}$ & Urban & $\begin{array}{l}\text { One semiconductor manufacturer making thin film } \\
\text { components, networks, and arrays on ceramic and } \\
\text { silicon; one company conducting waste management } \\
\text { providing service on hazardous waste removal, } \\
\text { hazardous waste transportation, oil tank hazardous } \\
\text { waste disposal } \\
\text { (https://www3.epa.gov/region } 1 / \text { removal- } \\
\text { sites/BradfordPrintingFinishing.html) }\end{array}$ & $\begin{array}{l}06 / 19 / \\
2014\end{array}$ & -71.46 & 41.70 \\
\hline 9 & $\begin{array}{l}\text { EG Town } \\
\text { Dock }\end{array}$ & $\mathrm{Y}$ & Urban & $\begin{array}{l}\text { Estuary of Greenwich Cove; next to an e-waste } \\
\text { recycling company }\end{array}$ & $\begin{array}{l}06 / 19 / \\
2014\end{array}$ & -71.45 & 41.65 \\
\hline 10 & Hunt River & $\mathrm{Y}$ & Urban & $\begin{array}{l}\text { Two semiconductor manufacturers and one printing } \\
\text { company }\end{array}$ & $\begin{array}{l}06 / 19 / \\
2014\end{array}$ & -71.44 & 41.64 \\
\hline 11 & $\begin{array}{l}\text { Sand Hill } \\
\text { Brook (Saw } \\
\text { Mill Pond } \\
\text { Inlet) }\end{array}$ & $\mathrm{N}$ & Urban & $\begin{array}{l}\text { A municipal waste transfer station and paint, coating, } \\
\text { adhesive manufacturing }\end{array}$ & $\begin{array}{l}06 / 19 / \\
2014\end{array}$ & -71.47 & 41.61 \\
\hline 12 & $\begin{array}{l}\text { Secret Lake- } \\
\text { Oak Hill } \\
\text { Brook }\end{array}$ & $\mathrm{N}$ & Urban & $\begin{array}{l}\text { A legacy landfill site is approximately } 2 \mathrm{~km} \text { to the } \\
\text { west of this site }\end{array}$ & $\begin{array}{l}06 / 19 / \\
2014\end{array}$ & -71.48 & 41.55 \\
\hline 13 & $\begin{array}{l}\text { Narrow } \\
\text { River Stuart } \\
\text { Stream }\end{array}$ & $\mathrm{N}$ & Rural & Outlet of Carr Pond & $\begin{array}{l}06 / 19 / \\
2014\end{array}$ & -71.44 & 41.52 \\
\hline 14 & Narrow & $\mathrm{N}$ & Rural & $3 \mathrm{~km}$ downstream of site 13 & $06 / 19 /$ & -71.45 & 41.49 \\
\hline
\end{tabular}




\begin{tabular}{|c|c|c|c|c|c|c|c|}
\hline 部 & : & 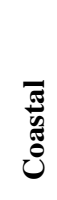 & 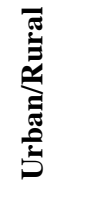 & 恶 & 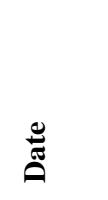 & 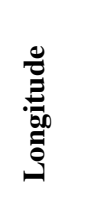 & : \\
\hline & $\begin{array}{l}\text { River } \\
\text { Lakeside } \\
\text { Dr. }\end{array}$ & & & & 2014 & & \\
\hline 15 & $\begin{array}{l}\text { Narrow } \\
\text { River }\end{array}$ & $\mathrm{N}$ & Rural & $2.5 \mathrm{~km}$ downstream of site 14 & $\begin{array}{l}06 / 19 / \\
2014\end{array}$ & -71.45 & 41.47 \\
\hline 16 & $\begin{array}{l}\text { Narrow } \\
\text { River }\end{array}$ & $\mathrm{N}$ & Rural & $2 \mathrm{~km}$ downstream of site 15 & $\begin{array}{l}06 / 19 / \\
2014\end{array}$ & -71.45 & 41.45 \\
\hline 17 & $\begin{array}{l}\text { Queens } \\
\text { River }\end{array}$ & $\mathrm{N}$ & Rural & $\begin{array}{l}\text { One river branch upstream of Pawcatuck River } \\
\text { (background site) }\end{array}$ & $\begin{array}{l}06 / 19 / \\
2014\end{array}$ & -71.56 & 41.54 \\
\hline 18 & $\begin{array}{l}\text { Chickashee } \\
\text { n Brook }\end{array}$ & $\mathrm{N}$ & Rural & $\begin{array}{l}\text { River branch upstream of Pawcatuck River; a } \\
\text { manufacturer of uninterruptible power supplies, } \\
\text { electronics peripherals and data center products is } \\
\text { downstream }\end{array}$ & $\begin{array}{l}06 / 19 / \\
2014\end{array}$ & -71.56 & 41.49 \\
\hline 19 & $\begin{array}{l}\text { Pawcatuck } \\
\text { River }\end{array}$ & $\mathrm{N}$ & Rural & $\begin{array}{l}\text { Where Beaver River merges into Pawcatuck River; a } \\
\text { manufacture of military, tactical, and performance } \\
\text { synthetic and synthetic blend textiles } \sim 1 \mathrm{~km} \text { upstream }\end{array}$ & $\begin{array}{l}06 / 19 / \\
2014\end{array}$ & -71.63 & 41.45 \\
\hline 20 & $\begin{array}{l}\text { Pawcatuck } \\
\text { River }\end{array}$ & $\mathrm{N}$ & Rural & $\begin{array}{l}\text { Adjacent to Bradford Printing \& Finishing facility, a } \\
\text { textile finishing plant from } 1911 \text { until 2012; a large } \\
\text { fire occurred in 2007; heavy flooding occured in } 2010 \text {; } \\
\text { another fire occurred in } 2012 \text {; Several hundred } \\
\text { containers of highly flammable liquid, dyes and } \\
\text { unknown compounds were stored next to each another } \\
\text { and many containers were visibly leaking in } 2012 .^{3}\end{array}$ & $\begin{array}{l}06 / 19 / \\
2014\end{array}$ & -71.75 & 41.41 \\
\hline 21 & $\begin{array}{l}\text { Green Falls } \\
\text { River }\end{array}$ & $\mathrm{N}$ & Rural & $\begin{array}{l}\text { Background site; no upstream industrial facilities } \\
\text { recorded in FRS database }\end{array}$ & $\begin{array}{l}06 / 19 / \\
2014\end{array}$ & -71.82 & 41.45 \\
\hline 22 & $\begin{array}{l}\text { Green Falls } \\
\text { River }\end{array}$ & $\mathrm{N}$ & Rural & $\begin{array}{l}\sim 2 \mathrm{~km} \text { downstream of site } 21 \text { where Parmenter Brook } \\
\text { merges into Green Falls River; no upstream industrial } \\
\text { facilities recorded in FRS database }\end{array}$ & $\begin{array}{l}06 / 19 / \\
2014\end{array}$ & -71.80 & 41.44 \\
\hline 23 & Fall River & $\mathrm{N}$ & Rural & $\begin{array}{l}\text { Background site; no upstream industrial facilities } \\
\text { recorded in FRS database }\end{array}$ & $\begin{array}{l}06 / 19 / \\
2014\end{array}$ & -71.69 & 41.58 \\
\hline 24 & $\begin{array}{l}\text { Allen Cove } \\
\text { - Inflow } \\
\text { (Green Hill } \\
\text { Pond) }\end{array}$ & $\mathrm{N}$ & Rural & Close to Charlestown beach; residential area & $\begin{array}{l}06 / 19 / \\
2014\end{array}$ & -71.62 & 41.37 \\
\hline 25 & $\begin{array}{l}\text { Bristol } \\
\text { Harbor }\end{array}$ & $\mathrm{Y}$ & Rural & Coastal site; east shore of Bristol Harbor & $\begin{array}{l}06 / 19 / \\
2014\end{array}$ & -71.29 & 41.67 \\
\hline 26 & $\begin{array}{l}\text { Bristol } \\
\text { Harbor }\end{array}$ & $\mathrm{Y}$ & Rural & Coastal site; east shore of Bristol Harbor & $\begin{array}{l}06 / 19 / \\
2014\end{array}$ & -71.28 & 41.67 \\
\hline 27 & $\begin{array}{l}\text { Bristol } \\
\text { Harbor }\end{array}$ & $\mathrm{Y}$ & Rural & Coastal site; west shore of Bristol Harbor & $\begin{array}{l}06 / 19 / \\
2014\end{array}$ & -71.27 & 41.66 \\
\hline 28 & $\begin{array}{l}\text { South Ferry } \\
\text { Rd Pier }\end{array}$ & $\mathrm{Y}$ & Rural & Coastal site; Narragansett Bay & $\begin{array}{l}06 / 19 / \\
2014\end{array}$ & -71.42 & 41.49 \\
\hline
\end{tabular}




\begin{tabular}{|c|c|c|c|c|c|c|c|}
\hline 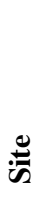 & : & 己े & 焉 & 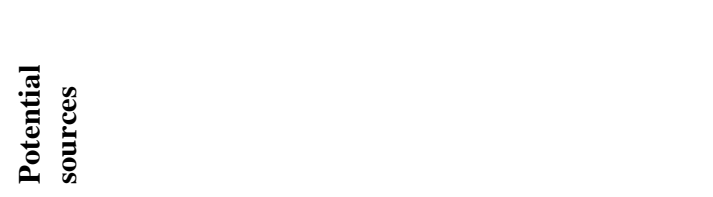 & ڤัँ & 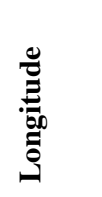 & : \\
\hline & Dock & & & & & & \\
\hline 29 & $\begin{array}{l}\text { Hudson } \\
\text { River }\end{array}$ & $\mathrm{N}$ & Urban & $\begin{array}{l}\text { There are a sewage treatment plant, a plastic bag } \\
\text { manufacturing and printing company, a printing ink } \\
\text { manufacture, and a floor coating manufacture within } \\
10 \mathrm{~km} \text { upstream along the river }\end{array}$ & $\begin{array}{l}10 / 24 / \\
2014\end{array}$ & -73.93 & 40.87 \\
\hline 30 & $\begin{array}{l}\text { Passaic } \\
\text { River }\end{array}$ & $\mathrm{N}$ & Urban & West Paterson Recycling Center $2.5 \mathrm{~km}$ upstream & $\begin{array}{l}10 / 24 / \\
2014\end{array}$ & -74.19 & 40.91 \\
\hline 31 & $\begin{array}{l}\text { Passaic } \\
\text { River }\end{array}$ & $\mathrm{N}$ & Urban & $\begin{array}{l}\text { Highly industrialized between } 30 \text { and } 31 \text {, including } \\
\text { paint, coating, adhesive manufacturing, textile mills, } \\
\text { printing ink manufactures, paper manufacturers; } \\
\text { semiconductor manufactures and metal coating/plating } \\
\text { companies. }\end{array}$ & $\begin{array}{l}10 / 24 / \\
2014\end{array}$ & -74.13 & 40.91 \\
\hline 32 & $\begin{array}{l}\text { Harbortown } \\
\text { Rd, NJ }\end{array}$ & Y & Urban & $\begin{array}{l}\text { At the mouth of a tidal strait and a kill separating } \\
\text { Staten Island, New York City from mainland New } \\
\text { Jersey; some petroleum/coal related industrials within } \\
2 \mathrm{~km} \text { upstreams }\end{array}$ & $\begin{array}{l}10 / 25 / \\
2014\end{array}$ & -74.25 & 40.52 \\
\hline 33 & $\begin{array}{l}\text { Lower NY } \\
\text { Harbor }\end{array}$ & $\mathrm{Y}$ & Urban & A printing ink manufacture $1 \mathrm{~km}$ away & $\begin{array}{l}10 / 25 / \\
2014\end{array}$ & -74.06 & 40.62 \\
\hline 34 & $\begin{array}{l}\text { Staten } \\
\text { Island NY }\end{array}$ & $\mathrm{N}$ & Urban & $\begin{array}{l}\text { A company with printing activity; a paint, coating, } \\
\text { adhesive manufacture, and a paper manufacture within } \\
1.5 \mathrm{~km} \text { upstream }\end{array}$ & $\begin{array}{l}10 / 25 / \\
2014\end{array}$ & -74.13 & 40.64 \\
\hline 35 & $\begin{array}{l}\text { Hudson } \\
\text { River }\end{array}$ & $\mathrm{Y}$ & Urban & $\begin{array}{l}\text { Morris Canal close to Jersey city; two companies on } \\
\text { Paint, coating, adhesive manufacturing } 1 \mathrm{~km} \text { away }\end{array}$ & $\begin{array}{l}10 / 26 / \\
2014\end{array}$ & -74.04 & 40.71 \\
\hline 36 & $\begin{array}{l}\text { Passaic } \\
\text { River }\end{array}$ & $\mathrm{N}$ & Urban & $\begin{array}{l}\text { Close to the city of Newark and the airport; highly } \\
\text { industrialized area; Newark wastewater treatment plant } \\
\text { is } 2.5 \mathrm{~km} \text { upstream }\end{array}$ & $\begin{array}{l}10 / 26 / \\
2014\end{array}$ & -74.15 & 40.73 \\
\hline 37 & $\begin{array}{l}\text { Passaic } \\
\text { River }\end{array}$ & $\mathrm{N}$ & Urban & $\begin{array}{l}\text { Upstream of site } 36 \text {; highly industrial area; within } 1 \\
\mathrm{~km} \text { upstream there is a company related to metal } \\
\text { plating and a textile mill. }\end{array}$ & $\begin{array}{l}10 / 26 / \\
2014\end{array}$ & -74.12 & 40.83 \\
\hline
\end{tabular}


96 Table S2. Full names and acronyms of PFASs measured in surface waters, limits of detection (LOD),

97 concentration ranges measured across sites, and percent of sites with detection. PFASs measured in

$98>60 \%$ of samples analyzed in this study are highlighted in bold

\begin{tabular}{|c|c|c|c|c|c|c|}
\hline PFAS & Acronym & $\begin{array}{l}\text { \# of } \\
\text { carbo } \\
\text { ns }\end{array}$ & Internal standard & $\begin{array}{l}\mathrm{LOD} \\
(\mathrm{ng} / \mathrm{L})\end{array}$ & $\begin{array}{l}\text { Range } \\
\text { (ng/L) }\end{array}$ & $\begin{array}{l}\text { Detect. } \\
\%\end{array}$ \\
\hline Perfluorocarboxylates & PFCAs & & & & & \\
\hline Perfluoropentanate & PFPeA & C5 & ${ }^{13} \mathrm{C}_{2}$-PFHxA & 0.38 & BD - 10 & $62 \%$ \\
\hline Perfluorohexanate & PFHxA & C6 & ${ }^{13} \mathrm{C}_{2}$-PFHxA & 0.29 & BD-48 & $87 \%$ \\
\hline Perfluoroheptanate & PFHрА & C7 & ${ }^{13} \mathrm{C}_{4}$-PFOA & 0.62 & BD-48 & $64 \%$ \\
\hline Perfluorooctanate & PFOA & C8 & ${ }^{13} \mathrm{C}_{4}$-PFOA & 0.07 & $\begin{array}{l}0.27- \\
47\end{array}$ & $100 \%$ \\
\hline Perfluorononanate & PFNA & C9 & ${ }^{13} \mathrm{C}_{5}$-PFNA & 0.04 & $\begin{array}{l}0.07- \\
14\end{array}$ & $100 \%$ \\
\hline Perfluorodecanate & PFDA & $\mathbf{C 1 0}$ & ${ }^{13} \mathrm{C}_{2}$-PFDA & 0.03 & $\begin{array}{l}\text { BD - } \\
5.8\end{array}$ & $92 \%$ \\
\hline Perfluoroundecanate & PFUnDA & C11 & ${ }^{13} \mathrm{C}_{2}$-PFUnDA & 0.02 & BD -1.9 & $77 \%$ \\
\hline Perfluorododecanate & PFDoDA & C12 & ${ }^{13} \mathrm{C}_{2}$-PFDoDA & 0.02 & BD-2.6 & $64 \%$ \\
\hline Perfluorotridecanate & PFTrDA & $\mathrm{C} 13$ & ${ }^{13} \mathrm{C}_{2}$-PFDoDA & 0.02 & BD-1.2 & $31 \%$ \\
\hline Perfluorotetradecanate & PFTeDA & $\mathrm{C} 14$ & ${ }^{13} \mathrm{C}_{2}$-PFDoDA & 0.02 & BD0.4 & $18 \%$ \\
\hline Perfluorohexaadecanate & PFHxDA & $\mathrm{C} 16$ & ${ }^{13} \mathrm{C}_{2}$-PFDoDA & 0.01 & BD- -0.2 & $26 \%$ \\
\hline Perfluorooctadecanate & PFODA & $\mathrm{C} 18$ & ${ }^{13} \mathrm{C}_{2}$-PFDoDA & 0.08 & $\mathrm{BD}-0.4$ & $8 \%$ \\
\hline Perfluoroalkane sulfonates & PFSAs & & & & & \\
\hline Perfluorobutane sulfonate & PFBS & $\mathrm{C4}$ & ${ }^{18} \mathrm{O}_{2}$-PFHxS & 0.08 & BD-6.2 & $85 \%$ \\
\hline Perfluorohexane sulfonate & PFHxS & C6 & ${ }^{18} \mathrm{O}_{2}-\mathrm{PFHxS}$ & 0.06 & BD -35 & $90 \%$ \\
\hline Perfluorooctane sulfonate & PFOS & $\mathrm{C8}$ & ${ }^{13} \mathrm{C}_{4}-\mathrm{PFOS}$ & 0.05 & BD -23 & $95 \%$ \\
\hline Perfluorododecane sulfonate & PFDS & $\mathrm{C} 10$ & ${ }^{13} \mathrm{C}_{4}$-PFOS & 0.07 & $\mathrm{BD}-0.6$ & $15 \%$ \\
\hline 6:2 fluorotelomer sulfonate & $6: 2 \mathrm{FtS}$ & & ${ }^{13} \mathrm{C}_{2}-6: 2 \mathrm{FtS}$ & 0.003 & BD -15 & $97 \%$ \\
\hline $8: 2$ fluorotelomer sulfonate & $8: 2 \mathrm{FtS}$ & & ${ }^{13} \mathrm{C}_{2}-6: 2 \mathrm{FtS}$ & 0.4 & $\mathrm{BD}-0.8$ & $41 \%$ \\
\hline Perfluorooctane sulfonamide & FOSA & $\mathrm{C} 8$ & ${ }^{13} \mathrm{C}_{8}$-FOSA & 0.02 & BD- -0.2 & $41 \%$ \\
\hline $\begin{array}{l}\text { N-ethyl } \\
\text { perfluorooctanesulfon- } \\
\text { amidoacetic acid }\end{array}$ & N-EtFOSAA & & $\mathrm{D}_{5} \mathrm{~N}$-EtFOSAA & 0.001 & BD-9.9 & $67 \%$ \\
\hline $\begin{array}{l}\mathrm{N} \text {-methyl } \\
\text { perfluorooctanesulfon- } \\
\text { amidoacetic acid }\end{array}$ & N-MeFOSAA & & $\begin{array}{l}\mathrm{D}_{5} \mathrm{~N}- \\
\text { MeFOSAA }\end{array}$ & 0.002 & BD-0.6 & $69 \%$ \\
\hline
\end{tabular}

$\mathrm{BD}=$ below detection. 

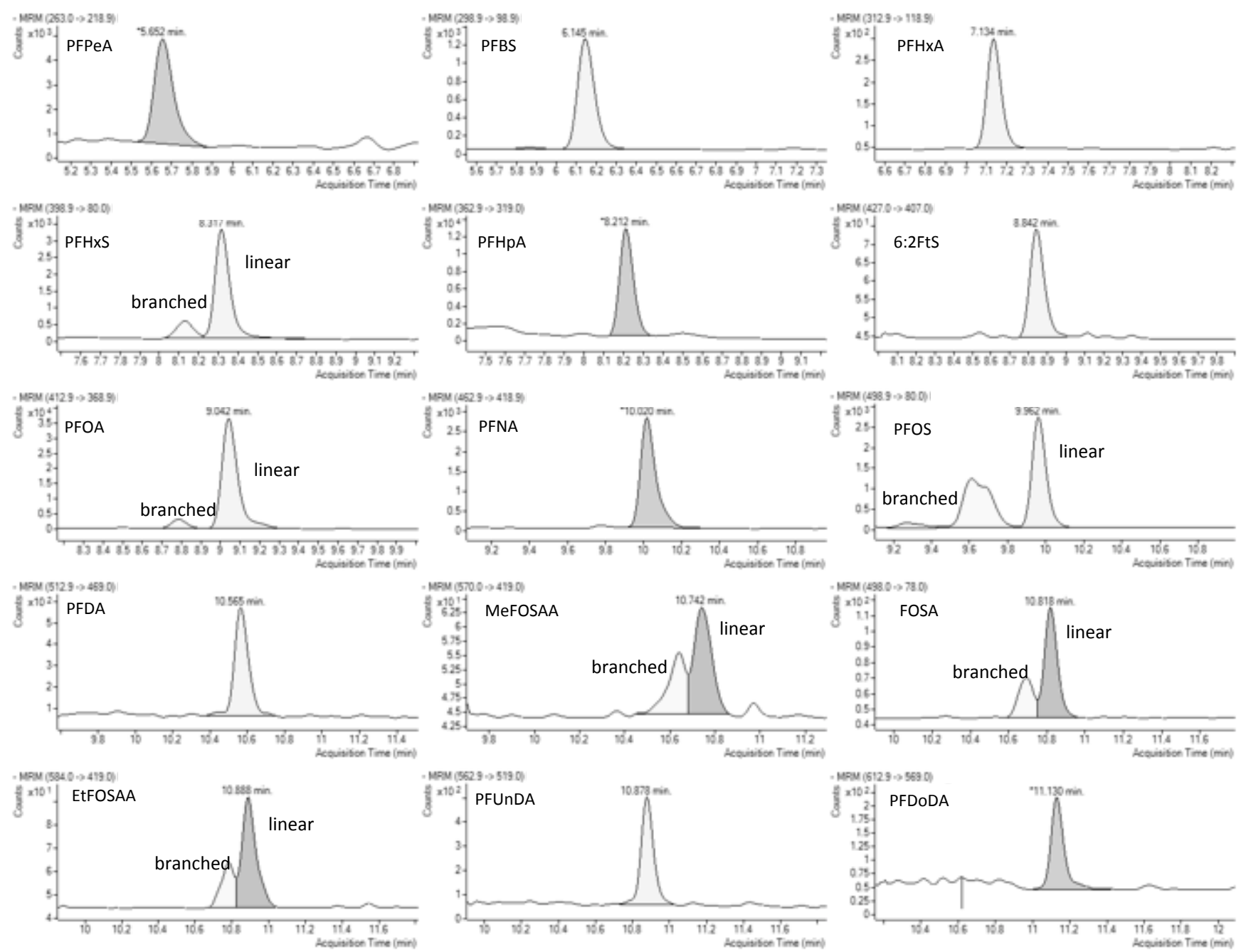

101 Figure S1. Chromatograms of PFASs in a sample analyzed using an Agilent 6460 LC-MS/MS

102 equipped with an online-SPE system (Agilent 1290 Infinity Flex Cube) in dynamic multiple reaction

103 mode. 
104 Table S3a. Concentrations (pg/L) of poly- and perfluoroalkyl substances with detection frequency 105 greater than $60 \%$.

\begin{tabular}{|c|c|c|c|c|c|c|c|}
\hline Site & PFPeA & PFHxA & PFHpA & $\mathrm{PFOA}^{\mathrm{a}}$ & PFNA & PFDA & PFUnDPA \\
\hline 1 & 4550 & 2191 & 2409 & 2363 & 390 & 405 & $607 \quad 108$ \\
\hline 2 & 10357 & 12137 & 13577 & 8832 & 3134 & 1133 & $\begin{array}{ll}308 \quad 100 \\
\end{array}$ \\
\hline 3 & $<\mathrm{LOD}$ & 6310 & 3371 & 5236 & 1476 & 894 & 1853110 \\
\hline 4 & 4228 & 7337 & 12301 & 7546 & 2735 & 957 & $114 \quad 111$ \\
\hline 5 & $<\mathrm{LOD}$ & 48414 & 48159 & 36806 & 13986 & 5625 & 1286112 \\
\hline 6 & 4359 & 5408 & 7640 & 8455 & 733 & 367 & $167 \quad 113$ \\
\hline 7 & 4828 & 6715 & 9236 & 10080 & 1275 & 205 & 114 \\
\hline 8 & 5611 & 5649 & $<\mathrm{LOD}$ & 9237 & 923 & 176 & 115 \\
\hline 9 & 927 & 1562 & 1597 & 1972 & 336 & 127 & $\begin{array}{ll}97 \quad 116\end{array}$ \\
\hline 10 & 3064 & 2987 & 3090 & 6978 & 308 & 125 & $<\operatorname{LOD}_{17}$ \\
\hline 11 & 6361 & 6678 & $<\mathrm{LOD}$ & 6905 & 799 & 226 & $\begin{array}{ll}177 \quad 118\end{array}$ \\
\hline 12 & 555 & 565 & $<\mathrm{LOD}$ & 849 & 165 & 59 & $\begin{array}{ll}38 & 119\end{array}$ \\
\hline 13 & 1413 & 1170 & $<\mathrm{LOD}$ & 1480 & 253 & 104 & $<\operatorname{LOD}_{20}$ \\
\hline 14 & $<\mathrm{LOD}$ & 665 & $<\mathrm{LOD}$ & 663 & 104 & $<\mathrm{LOD}$ & $\begin{array}{ll}33 & 121\end{array}$ \\
\hline 15 & 732 & 556 & $<\mathrm{LOD}$ & 851 & 136 & 31 & $<\operatorname{LOD}_{22}$ \\
\hline 16 & 631 & 543 & $<\mathrm{LOD}$ & 946 & 174 & 87 & $\begin{array}{ll}62 \quad 123\end{array}$ \\
\hline 17 & 681 & 550 & $<\mathrm{LOD}$ & 898 & 155 & 59 & $\begin{array}{ll}62 & 124\end{array}$ \\
\hline 18 & 2138 & 663 & $<\mathrm{LOD}$ & 1006 & 293 & $<\mathrm{LOD}$ & $<\operatorname{LOD}_{125}$ \\
\hline 19 & $<\mathrm{LOD}$ & 3740 & 11793 & 18974 & 6182 & 3808 & $482 \quad 126$ \\
\hline 20 & $<\mathrm{LOD}$ & 4138 & 9728 & 14985 & 7235 & 5824 & 888 \\
\hline 21 & $<\mathrm{LOD}$ & $<\mathrm{LOD}$ & $<\mathrm{LOD}$ & 586 & 232 & 73 & $\begin{array}{ll}41 \quad 128\end{array}$ \\
\hline 22 & $<\mathrm{LOD}$ & 493 & $<\mathrm{LOD}$ & 708 & 206 & 83 & $<\mathrm{LOD}_{29}$ \\
\hline 23 & $<\mathrm{LOD}$ & $<\mathrm{LOD}$ & $<\mathrm{LOD}$ & 640 & 200 & 152 & $\begin{array}{ll}97 & 130\end{array}$ \\
\hline 24 & 1221 & 2121 & 2479 & 3784 & 260 & 52 & 131 \\
\hline 25 & 843 & 1214 & 897 & 1320 & 400 & 169 & $\begin{array}{ll}97 \quad 132\end{array}$ \\
\hline 26 & 821 & 964 & 751 & 1014 & 323 & 134 & $<\mathrm{LOD}_{33}$ \\
\hline 27 & 617 & 900 & 800 & 1170 & 355 & 166 & $\begin{array}{ll}78 \quad 134 \\
\end{array}$ \\
\hline 28 & $<\mathrm{LOD}$ & $<\mathrm{LOD}$ & $<\mathrm{LOD}$ & 267 & 74 & 38 & $<\mathrm{LOD}_{35}$ \\
\hline 29 & $<\mathrm{LOD}$ & $<\mathrm{LOD}$ & $<\mathrm{LOD}$ & 11862 & 2188 & 685 & $257 \quad 136$ \\
\hline 30 & $<\mathrm{LOD}$ & 815 & 947 & 871 & 151 & 59 & 137 \\
\hline 31 & $<\mathrm{LOD}$ & $<\mathrm{LOD}$ & $<\mathrm{LOD}$ & 47254 & 6658 & 2154 & $\begin{array}{ll}464 & 138\end{array}$ \\
\hline 32 & 3032 & 3529 & 3226 & 3738 & 601 & 301 & $<\operatorname{LOD}_{139}$ \\
\hline 33 & 1870 & 1802 & 1907 & 2020 & 363 & 182 & $\begin{array}{ll}49 \quad 140\end{array}$ \\
\hline 34 & 3434 & 5188 & 3431 & 4049 & 726 & 347 & 115 \\
\hline 35 & 1111 & 1710 & 1852 & 2805 & 411 & 211 & 142 \\
\hline 36 & 7998 & 9277 & 3426 & 15137 & 2022 & 719 & 238 \\
\hline 37 & $<$ LOD & 10901 & 8455 & 11335 & 757 & 152 & 144 \\
\hline
\end{tabular}

145

${ }^{a}$ Linear isomers with calibration standards for quantification 
146 Table S3b. Concentrations (pg/L) of poly- and perfluoroalkyl substances with detection frequency 147 greater than $60 \%$.

\begin{tabular}{|c|c|c|c|c|c|c|c|}
\hline Site & PFBS & $\mathrm{PFHxS}^{\mathrm{a}}$ & PFOS $^{\mathrm{a}}$ & $6: 2 \mathrm{FtS}$ & MeFOSAA $^{\mathrm{a}}$ & EtFOSAA $^{a}$ & PFDoPA \\
\hline 1 & 669 & 864 & 777 & 15 & 241 & 348 & 618 \\
\hline 2 & 1652 & 3758 & 23226 & 15292 & 147 & 278 & 89 \\
\hline 3 & 1327 & 3583 & 5868 & 55 & 610 & 937 & 2598152 \\
\hline 4 & 2290 & 2558 & 2185 & 380 & 227 & 152 & $28 \quad 153$ \\
\hline 5 & 6181 & 35022 & 9804 & 239 & 113 & 240 & $117 \quad 154$ \\
\hline 6 & 1087 & 2637 & 4127 & 24 & 90 & 694 & $\begin{array}{ll}96 & 155\end{array}$ \\
\hline 7 & 2102 & 4130 & 3743 & 30 & $<\mathrm{LOD}$ & 122 & $<$ LOP56 \\
\hline 8 & 3355 & 4664 & 3937 & 9 & 23 & 53 & $23 \quad 157$ \\
\hline 9 & 296 & 695 & 735 & 26 & 38 & 65 & $\begin{array}{ll}61 \quad 158\end{array}$ \\
\hline 10 & 1161 & 5075 & 1477 & 8 & $<\mathrm{LOD}$ & 36 & $<$ LOP59 \\
\hline 11 & 546 & 2418 & 1822 & 5 & 106 & 94 & 313160 \\
\hline 12 & 278 & $<\mathrm{LOD}$ & $<\mathrm{LOD}$ & $<$ LOD & 43 & 14 & $\begin{array}{ll}25 & 161\end{array}$ \\
\hline 13 & 889 & 645 & 347 & 6 & $<\mathrm{LOD}$ & $<\mathrm{LOD}$ & $<$ LOP62 \\
\hline 14 & 368 & 476 & 176 & $<$ LOD & $<\mathrm{LOD}$ & $<\mathrm{LOD}$ & $<$ LOP63 \\
\hline 15 & 705 & 421 & 180 & 10 & $<\mathrm{LOD}$ & $<\mathrm{LOD}$ & $<$ LOP64 \\
\hline 16 & 226 & 323 & 488 & 3 & 82 & $<\mathrm{LOD}$ & $131 \quad 165$ \\
\hline 17 & 466 & 372 & 334 & 7 & 82 & $<\mathrm{LOD}$ & $131 \quad 166$ \\
\hline 18 & 973 & 208 & $<\mathrm{LOD}$ & 10 & 27 & $<\mathrm{LOD}$ & $<$ LOP67 \\
\hline 19 & 2485 & $<\mathrm{LOD}$ & 509 & 10 & 60 & $<\mathrm{LOD}$ & 194168 \\
\hline 20 & 1465 & 361 & 612 & 4 & 159 & 24 & $\begin{array}{ll}35 & 169\end{array}$ \\
\hline 21 & 92 & $<\mathrm{LOD}$ & 290 & 10 & 34 & $<\mathrm{LOD}$ & $24 \quad 170$ \\
\hline 22 & 341 & 133 & 292 & 13 & 39 & $<\mathrm{LOD}$ & $<\mathrm{LOP}_{71}$ \\
\hline 23 & $<\mathrm{LOD}$ & 143 & 238 & 12 & $<\mathrm{LOD}$ & $<\mathrm{LOD}$ & $\begin{array}{ll}42 \quad 172\end{array}$ \\
\hline 24 & 1185 & 916 & 1198 & 6 & 55 & 46 & $41 \quad 173$ \\
\hline 25 & 281 & 343 & 626 & 16 & $<\mathrm{LOD}$ & 49 & $<\mathrm{LOP}_{74}$ \\
\hline 26 & 254 & 282 & 437 & 12 & 47 & $<\mathrm{LOD}$ & $<\mathrm{LOP}_{75}$ \\
\hline 27 & 229 & 320 & 460 & 22 & 80 & 58 & $<\mathrm{LOP}_{76}$ \\
\hline 28 & 131 & $<\mathrm{LOD}$ & 161 & 4 & $<\mathrm{LOD}$ & $<\mathrm{LOD}$ & $<\mathrm{LOP}_{77}$ \\
\hline 29 & $<\mathrm{LOD}$ & 2149 & 2835 & 1087 & 160 & 148 & $\begin{array}{ll}59 & 178\end{array}$ \\
\hline 30 & 220 & 224 & 244 & 69 & $<\mathrm{LOD}$ & $<\mathrm{LOD}$ & $<$ LOP79 \\
\hline 31 & $<\mathrm{LOD}$ & 8526 & 9988 & 4377 & 166 & 593 & $99 \quad 180$ \\
\hline 32 & $<\mathrm{LOD}$ & 1390 & 1929 & 464 & 32 & 59 & 181 \\
\hline 33 & 226 & 408 & 755 & 58 & $<\mathrm{LOD}$ & 48 & 182 \\
\hline 34 & 467 & 963 & 1661 & 5918 & $<\mathrm{LOD}$ & 92 & $34 \quad 183$ \\
\hline 35 & 278 & 640 & 790 & 82 & 33 & 31 & $<$ LOP 84 \\
\hline 36 & $<$ LOD & 3087 & 5384 & 89 & 40 & 57 & $\begin{array}{ll}99 & 185\end{array}$ \\
\hline 37 & $<\mathrm{LOD}$ & 3162 & 2748 & 43 & $<\mathrm{LOD}$ & 18 & $128 \quad 186$ \\
\hline
\end{tabular}

187

${ }^{a}$ Linear isomers with calibration standards for quantification 
188

189 Table S3c. Concentrations (pg/L) of branched isomers ${ }^{\mathrm{a}}$ of poly- and perfluoroalkyl substances

\begin{tabular}{|c|c|c|c|c|c|}
\hline Site & br-PFHxS & br-PFOA & br-PFOS & br-MeFOSAA & br-EtFOSAA \\
\hline 1 & 201 & 550 & 181 & 56 & 81 \\
\hline 2 & 695 & 1635 & 4298 & 27 & 51 \\
\hline 3 & 777 & 1135 & 1272 & 132 & 203 \\
\hline 4 & 590 & 1741 & 504 & 52 & 35 \\
\hline 5 & 8228 & 8647 & 2303 & 27 & 56 \\
\hline 6 & 481 & 1542 & 753 & $<17$ & 127 \\
\hline 7 & 741 & 1808 & 671 & $<17$ & 22 \\
\hline 8 & 896 & 1775 & 756 & $<17$ & $<12$ \\
\hline 9 & $<64$ & 114 & $<51$ & $<17$ & $<12$ \\
\hline 10 & 982 & 1350 & 286 & $<17$ & $<12$ \\
\hline 11 & 483 & 1378 & 364 & 21 & 19 \\
\hline 12 & $<64$ & 249 & $<51$ & $<17$ & $<12$ \\
\hline 13 & 76 & 174 & $<51$ & $<17$ & $<12$ \\
\hline 14 & 76 & 106 & $<51$ & $<17$ & $<12$ \\
\hline 15 & $<64$ & 125 & $<51$ & $<17$ & $<12$ \\
\hline 16 & $<64$ & 146 & 75 & $<17$ & $<12$ \\
\hline 17 & $<64$ & 118 & $<51$ & $<17$ & $<12$ \\
\hline 18 & $<64$ & 151 & $<51$ & $<17$ & $<12$ \\
\hline 19 & $<64$ & 3015 & 81 & $<17$ & $<12$ \\
\hline 20 & 78 & 3250 & 133 & 35 & $<12$ \\
\hline 21 & $<64$ & 74 & $<51$ & $<17$ & $<12$ \\
\hline 22 & $<64$ & $<68$ & $<51$ & $<17$ & $<12$ \\
\hline 23 & $<64$ & $<68$ & $<51$ & $<17$ & $<12$ \\
\hline 24 & 164 & 678 & 215 & $<17$ & $<12$ \\
\hline 25 & 80 & 306 & 145 & $<17$ & $<12$ \\
\hline 26 & 93 & 333 & 144 & $<17$ & $<12$ \\
\hline 27 & $<64$ & 227 & 89 & $<17$ & $<12$ \\
\hline 28 & $<64$ & 284 & 171 & $<17$ & $<12$ \\
\hline 29 & 471 & 2602 & 622 & 35 & 32 \\
\hline 30 & $<64$ & 193 & 54 & $<17$ & $<12$ \\
\hline 31 & 1578 & 8745 & 1848 & 31 & 110 \\
\hline 32 & 294 & 790 & 408 & $<17$ & 12 \\
\hline 33 & 113 & 557 & 208 & $<17$ & 13 \\
\hline 34 & 176 & 739 & 303 & $<17$ & 17 \\
\hline 35 & 158 & 691 & 195 & $<17$ & $<12$ \\
\hline 36 & 539 & 2660 & 953 & $<17$ & $<12$ \\
\hline 37 & 700 & 2512 & 609 & $<17$ & $<12$ \\
\hline
\end{tabular}

$190 \quad{ }^{a}$ Branched isomers were quantified based on peak areas assuming the same response factors as the 191 linear isomers. 
192 Table S4. PFAS concentrations measured in U.S. surface waters in this study and previous work.

PFASs, ng/L (minimum/median/maximum)

\begin{tabular}{|c|c|c|c|c|c|c|c|c|c|c|c|}
\hline $\begin{array}{c}\text { Location/ } \\
\text { (sites, } \\
\text { sampling year) }\end{array}$ & PFPeA & PFHxA & РFHрA & PFOA & PFNA & PFDA & PFUnDA & PFDoDA & PFBS & PFHxS & PFOS \\
\hline \multirow{3}{*}{$\begin{array}{c}\text { Tennessee } \\
(n=40,2000)^{4}\end{array}$} & & & & $<25$ & & & & & & & 17 \\
\hline & & & & $<25$ & & & & & & & 52 \\
\hline & & & & 598 & & & & & & & 144 \\
\hline \multirow{3}{*}{$\begin{array}{l}\text { North Carolina } \\
(n=11,2006)\end{array}$} & & $<1$ & $<1$ & $<1$ & $<1$ & $<1$ & $<1$ & $<1$ & $<1$ & $<1$ & $<1$ \\
\hline & & 5.14 & 14.8 & 12.6 & 5.7 & 13.2 & 5.67 & 1.95 & 2.46 & 5.66 & 28.9 \\
\hline & & 23 & 329 & 287 & 194 & 120 & 52.1 & 4.46 & 9.41 & 35.1 & 132 \\
\hline \multirow{3}{*}{$\begin{array}{c}\text { Georgia } \\
(n=11,2006)\end{array}$} & & & & 3 & $<0.6$ & $<0.1$ & $<0.1$ & & & & 1 \\
\hline & & & & 238 & 5.6 & 2.1 & $<0.1$ & & & & 6 \\
\hline & & & & 1150 & 369 & 131 & 99 & & & & 318 \\
\hline \multirow{3}{*}{$\begin{array}{c}\text { Upper } \\
\text { Mississippi } \\
\text { River Basin } \\
(n=177,2008) \\
\end{array}$} & $<\mathrm{LOQ}$ & $<$ LOQ & $<$ LOQ & $<$ LOQ & $<\mathrm{LOQ}$ & $<\mathrm{LOQ}$ & $<\mathrm{LOQ}$ & $<\mathrm{LOQ}$ & $<\mathrm{LOQ}$ & $<\mathrm{LOQ}$ & $<\mathrm{LOQ}$ \\
\hline & 0.71 & 1.59 & 2.16 & 2.07 & 0.71 & 0.71 & 0.71 & 0.71 & 0.71 & 0.71 & 3.01 \\
\hline & 31.5 & 53.4 & 90.2 & 125 & 72.9 & 42 & 29.1 & 24.7 & 84.1 & 169 & 245 \\
\hline \multirow{3}{*}{$\begin{array}{c}\text { Georgia } \\
(\boldsymbol{n}=\mathbf{8}, \mathbf{2 0 0 8})\end{array}$} & $<\mathrm{MDL}$ & $<\mathrm{MDL}$ & $<\mathrm{MDL}$ & $<\mathrm{MDL}$ & $<\mathrm{MDL}$ & $<\mathrm{MDL}$ & $<\mathrm{MDL}$ & $<\mathrm{MDL}$ & $<\mathrm{MDL}$ & $<\mathrm{MDL}$ & $<\mathrm{MDL}$ \\
\hline & 57 & 68 & 46 & 102 & 21 & 25 & & & 124 & 13 & 150 \\
\hline & 149 & 149 & 100 & 204 & 46 & 46 & & & 260 & 31 & 321 \\
\hline \multirow{3}{*}{$\begin{array}{c}\text { New Jersey } \\
(n=12,2009)\end{array}$} & $<5$ & $<5$ & $<5$ & $<5$ & $<5$ & $<5$ & & & $<5$ & $<5$ & $<5$ \\
\hline & $<5$ & $<5$ & $<5$ & 11 & $<5$ & $<5$ & & & $<5$ & $<5$ & $<5$ \\
\hline & 15 & 17 & 10 & 100 & 19 & ND & & & 6 & 46 & 43 \\
\hline \multirow{3}{*}{$\begin{array}{c}\text { Rhode Island } \\
\text { and New York } \\
\text { Metropolitan } \\
\text { Region ( } n=37 \\
\text { 2014, this } \\
\text { study)* }\end{array}$} & $<0.4$ & $<0.3$ & $<0.6$ & 0.3 & 0.1 & $<0.03$ & $<0.03$ & $<0.03$ & $<0.08$ & $<0.12$ & $<0.10$ \\
\hline & 0.8 & 1.7 & 0.9 & 3.5 & 0.4 & 0.2 & 0.1 & 0.0 & 0.4 & 0.7 & 0.96 \\
\hline & 10.4 & 48.4 & 48.2 & 56.0 & 14.0 & 5.8 & 1.9 & 2.6 & 6.2 & 43.0 & 27.5 \\
\hline
\end{tabular}

193 *PFOA, PFHxS and PFOS reported here include both linear and branched isomers. The branched

194 isomers were quantified based on peak areas assuming the same response factors as the linear isomers 


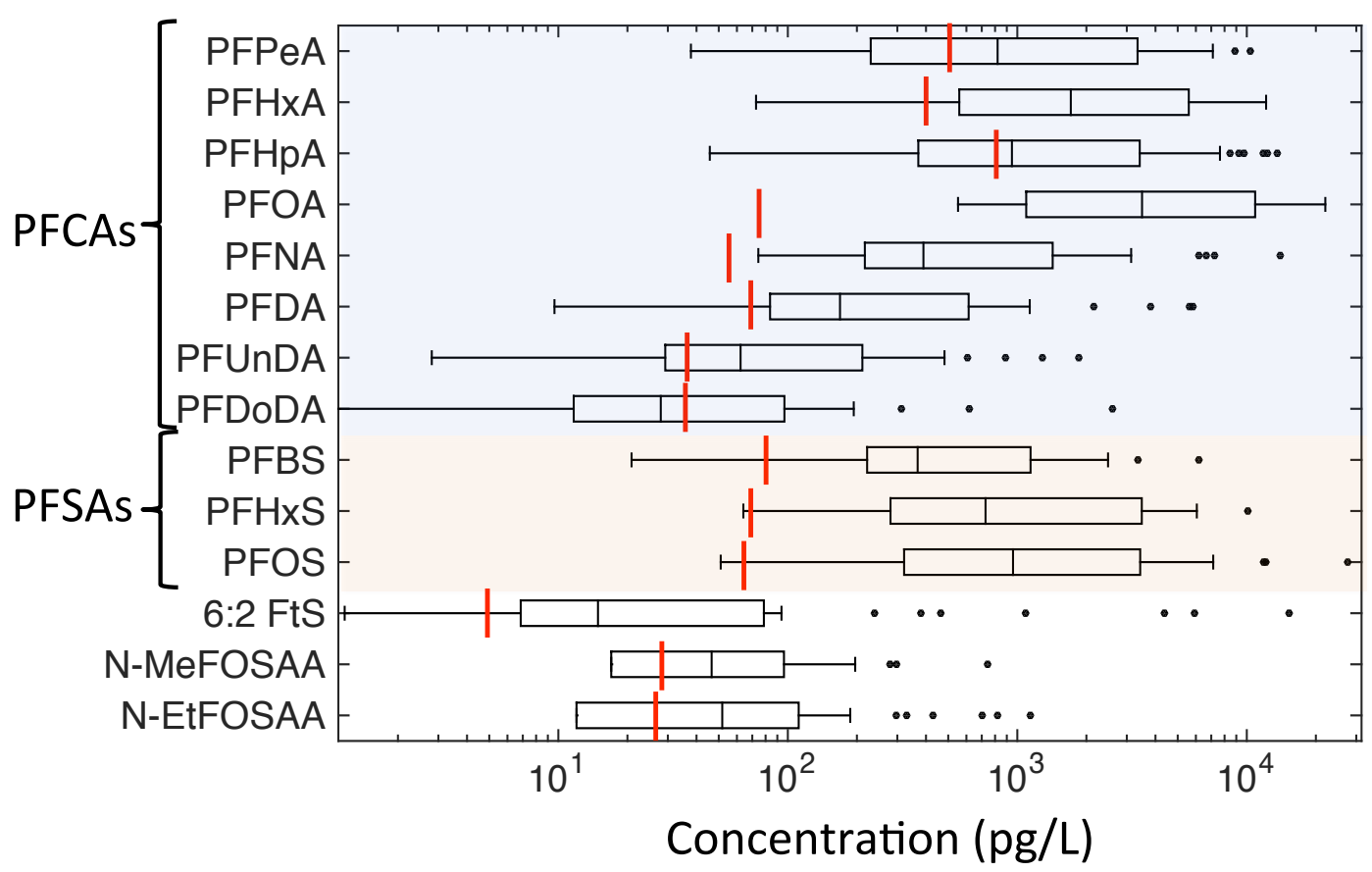

198 Figure S2. Concentrations of 14-PFASs measured in 37 rivers and estuaries in Rhode Island (RI) and 199 the New York Metropolitan area (NY/NJ). The limit of detection (LOD) for each compound is shown 200 as a red bar. Those below detection are assigned values based on the robust ROS (Regression on 201 Order Statistics) approach for censored log-normally distributed environmental data as described by 202 Helsel. $^{2}$ 

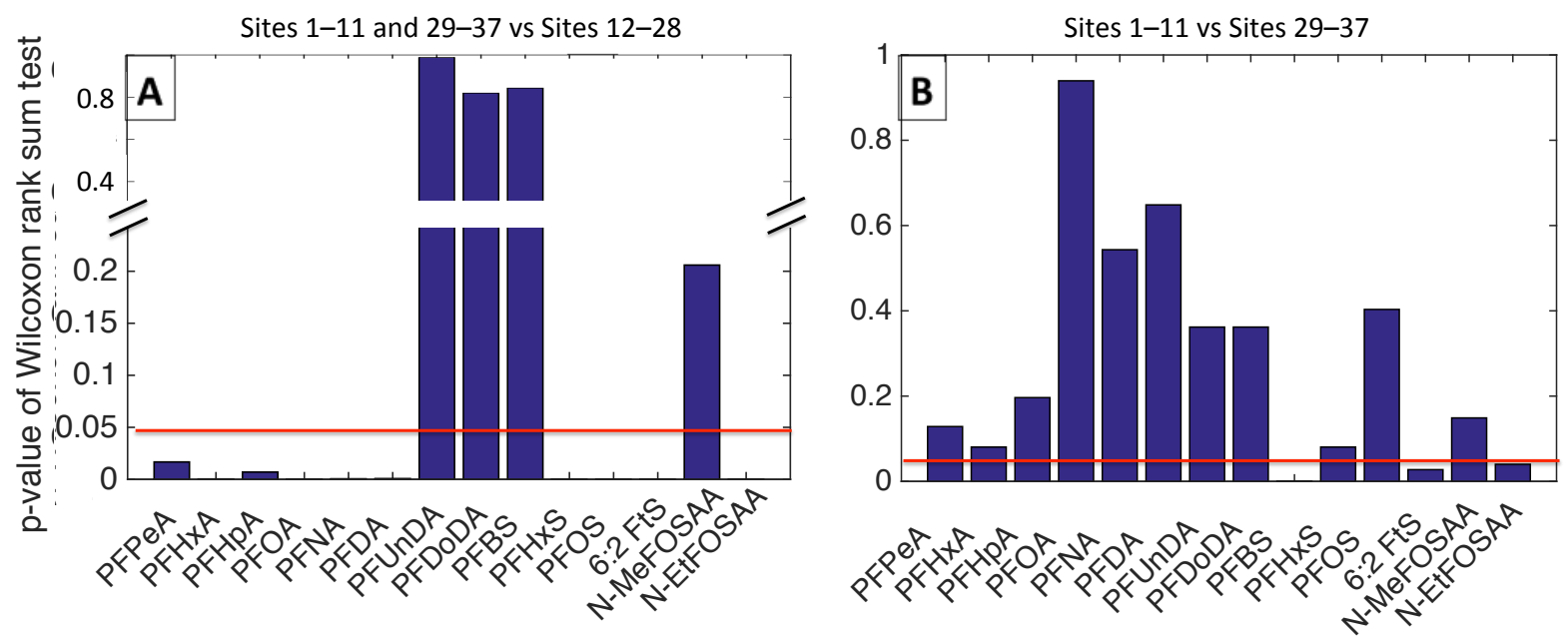

203

204 Figure S3. Significance levels for Wilcoxon rank sum tests comparing PFAS concentrations (a) 205 between urban sites (RI sites 1-11 and NY/NJ sites 29-37) and rural sites 12-28 (b) RI sites 1-11 and $206 \mathrm{NY} / \mathrm{NJ}$ sites 29-37. Red line denotes $p=0.05$, which we use to indicate statistical significance. 


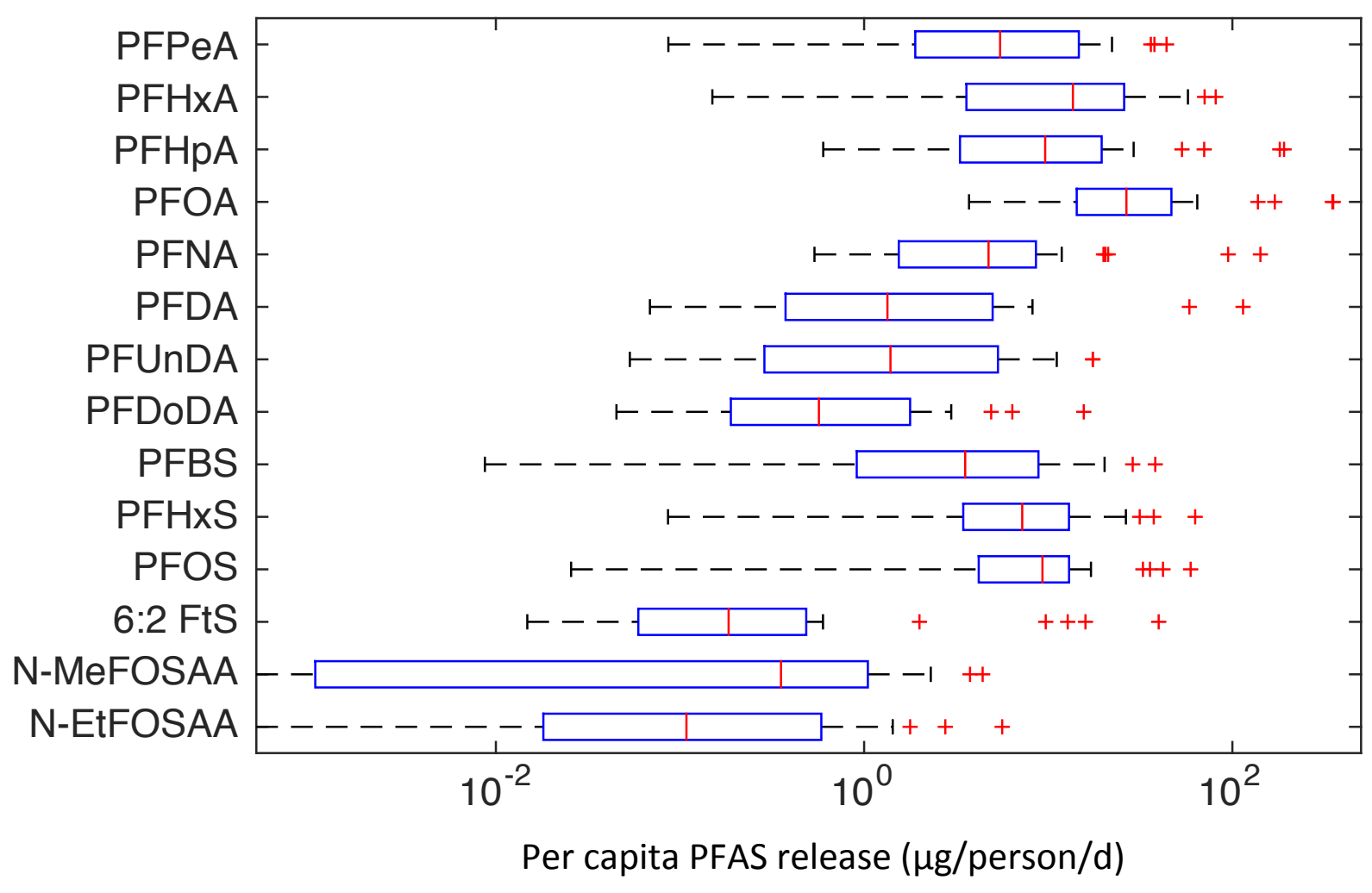

210 Figure S4. Per-capita release of PFAS ( $\mu \mathrm{g} / \mathrm{person} / \mathrm{d})$ estimated based on measured PFAS

211 concentrations, water flow rate and upstream population at each sampling site. 
- Waste Management

- Printing Activity

- Sewage Treatment

- Metal Coating Plating

Paint, Coating, Adhesive Manufacturing
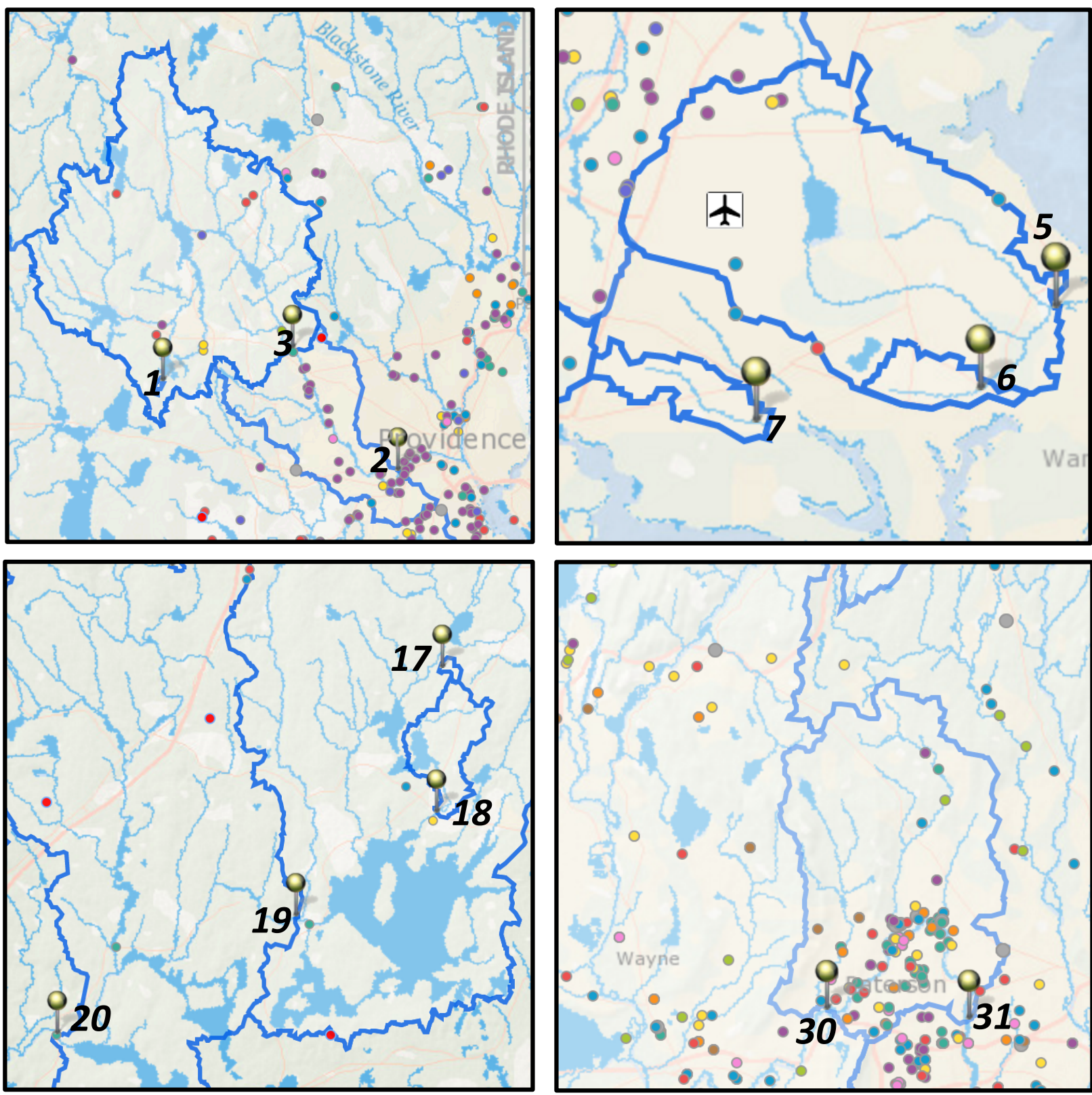

213 Figure S5. Maps showing sampling sites with distinct PFAS composition profiles, the upstream 214 watersheds and the potential source contributions.
- Semiconductor Manufacturing

- Paper Manufacturing

- Petroleum Coal

- Textile Mills

- Petroleum Coal Products Manufacturing

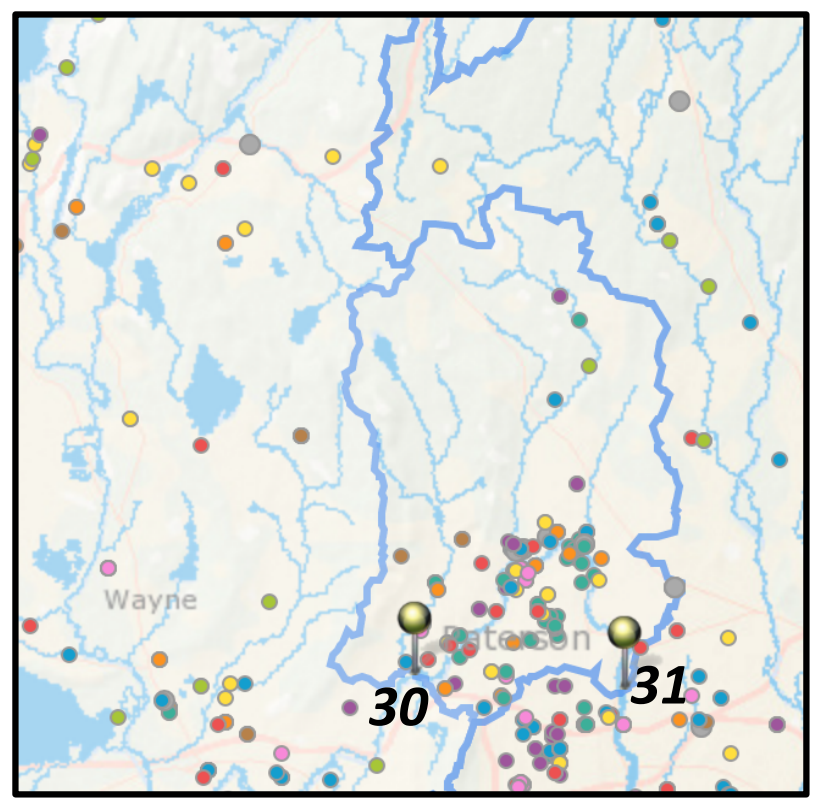


215 Table S5. Impact factors for potential PFAS sources in watersheds upstream of the non-estuarine 216 sampling sites.

\begin{tabular}{|c|c|c|c|c|c|c|c|c|c|c|c|c|c|c|}
\hline & & & & & & & & Impact frc & facilities & upstreams & & & & \\
\hline$\stackrel{\mathscr{w}}{\frac{ \pm}{n}}$ & 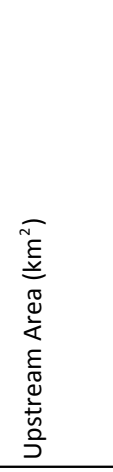 & 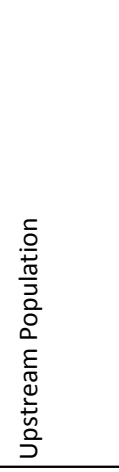 & 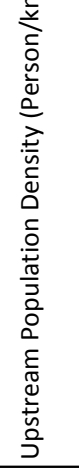 & 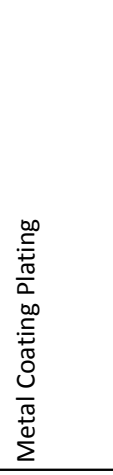 & 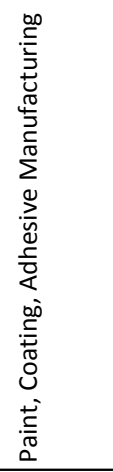 & 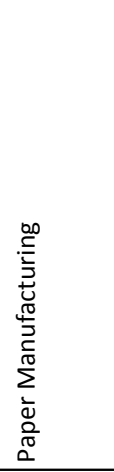 & 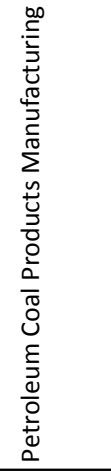 & 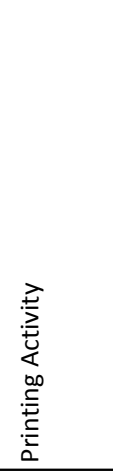 & 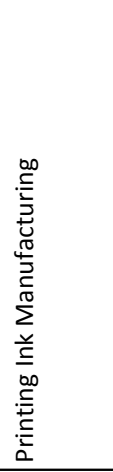 & 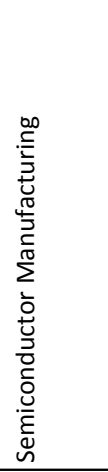 & 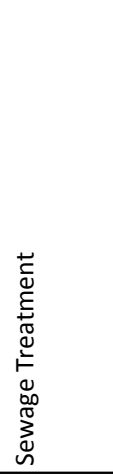 & 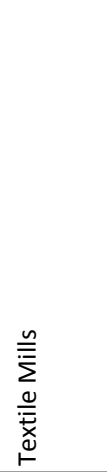 & 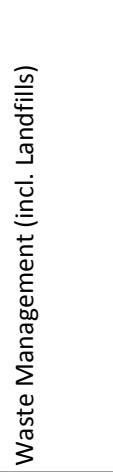 & $\begin{array}{l}\frac{5}{0} \\
\frac{0}{2} \\
\text { : }\end{array}$ \\
\hline 1 & 0.1 & 26 & 190 & & & & & & & & & & & \\
\hline 2 & 124.4 & 87446 & 703 & $1.7 \mathrm{E}+00$ & $3.7 \mathrm{E}-01$ & $1.3 \mathrm{E}-02$ & $2.6 \mathrm{E}-01$ & $5.5 \mathrm{E}-05$ & & $5.1 \mathrm{E}-01$ & & $1.1 \mathrm{E}-01$ & $5.5 \mathrm{E}-08$ & \\
\hline 3 & 97.6 & 24495 & 251 & $3.2 \mathrm{E}-04$ & & $1.7 \mathrm{E}-06$ & & & & $1.2 \mathrm{E}-06$ & $3.7 \mathrm{E}-01$ & & $3.5 \mathrm{E}-04$ & \\
\hline 4 & 598.2 & 208255 & 348 & $1.3 \mathrm{E}-01$ & $5.2 \mathrm{E}-04$ & $1.7 \mathrm{E}-04$ & $5.8 \mathrm{E}-04$ & $5.5 \mathrm{E}-03$ & $1.4 \mathrm{E}-08$ & $2.8 \mathrm{E}-02$ & $4.9 \mathrm{E}-03$ & 1.7E-04 & $1.6 \mathrm{E}-01$ & \\
\hline 5 & 16.0 & 16509 & 1032 & $9.9 \mathrm{E}-04$ & & & & $3.0 \mathrm{E}-03$ & & & & & $3.4 \mathrm{E}-04$ & 4.1E-03 \\
\hline 6 & 1.0 & 1174 & 1196 & & & & & & & & & & & \\
\hline 7 & 1.4 & 1792 & 1306 & & & & & & & & & & & \\
\hline 8 & 15.9 & 12476 & 783 & 7.1E-01 & & & $2.5 \mathrm{E}-04$ & $6.1 \mathrm{E}-04$ & & $6.0 \mathrm{E}-01$ & & & & \\
\hline 10 & 59.3 & 14886 & 251 & 4.4E-03 & $1.3 \mathrm{E}-03$ & & & $9.1 \mathrm{E}-05$ & & $3.3 \mathrm{E}-04$ & & & $3.0 \mathrm{E}-04$ & \\
\hline 11 & 5.5 & 1394 & 254 & & 2.1E-01 & & & & & & & & $6.9 \mathrm{E}-01$ & \\
\hline 12 & 0.6 & 123 & 218 & & & & & & & & & & & \\
\hline 13 & 12.1 & 1951 & 161 & & & & & & & & & & & \\
\hline 14 & 21.2 & 4811 & 226 & & & & & & & & & & & \\
\hline 15 & 24.4 & 5870 & 240 & & & & & & & & & & & \\
\hline 16 & 33.8 & 8835 & 262 & & & & & & & & & & & \\
\hline 17 & 0.5 & 20 & 42 & & & & & & & & & & & \\
\hline 18 & 10.2 & 746 & 73 & & & & & & & & & & & \\
\hline 19 & 235.3 & 23112 & 98 & & & & & $2.0 \mathrm{E}-04$ & & $4.3 \mathrm{E}-05$ & & $3.9 \mathrm{E}-01$ & & \\
\hline 20 & 561.1 & 43081 & 77 & & & $3.8 \mathrm{E}-15$ & & $4.8 \mathrm{E}-13$ & & $1.1 \mathrm{E}-13$ & & $9.1 \mathrm{E}-01$ & & \\
\hline 21 & 0.01 & 1 & 69 & & & & & & & & & & & \\
\hline 22 & 65.7 & 2647 & 40 & & & & & & & & & & & \\
\hline 23 & 0.3 & 12 & 44 & & & & & & & & & & & \\
\hline 29 & 12799.8 & 1994644 & 156 & $9.6 \mathrm{E}-02$ & $1.4 \mathrm{E}+00$ & $2.2 \mathrm{E}+00$ & $4.9 \mathrm{E}-09$ & $5.6 \mathrm{E}+00$ & $2.0 \mathrm{E}+00$ & 7.5E-02 & $3.6 \mathrm{E}+00$ & $2.8 \mathrm{E}-01$ & $1.8 \mathrm{E}+00$ & \\
\hline 30 & 2015.8 & 854842 & 424 & $1.2 \mathrm{E}-02$ & 4.7E-03 & $6.5 \mathrm{E}-04$ & $8.0 \mathrm{E}-04$ & $9.8 \mathrm{E}-02$ & $1.8 \mathrm{E}-05$ & $6.3 \mathrm{E}-02$ & $9.4 \mathrm{E}-04$ & $3.8 \mathrm{E}-03$ & $3.8 \mathrm{E}-04$ & \\
\hline 31 & 2090.0 & 1050694 & 503 & $3.2 \mathrm{E}-02$ & $1.1 \mathrm{E}-01$ & $2.6 \mathrm{E}-02$ & 7.6E-04 & $4.2 \mathrm{E}-02$ & $1.6 \mathrm{E}-01$ & $1.2 \mathrm{E}-01$ & $2.4 \mathrm{E}-04$ & $1.6 \mathrm{E}-01$ & $3.1 \mathrm{E}-02$ & \\
\hline 34 & 3345.1 & 3737691 & 1117 & $2.1 \mathrm{E}-01$ & $5.2 \mathrm{E}-04$ & $1.8 \mathrm{E}-01$ & $6.2 \mathrm{E}-03$ & 2.7E-01 & $1.5 \mathrm{E}-04$ & 3.6E-01 & $2.9 \mathrm{E}-03$ & 1.7E-01 & $6.1 \mathrm{E}-02$ & $2.5 \mathrm{E}-04$ \\
\hline 36 & 2406.9 & 1903628 & 791 & $1.7 \mathrm{E}+00$ & $3.5 \mathrm{E}-01$ & $1.8 \mathrm{E}-01$ & $4.2 \mathrm{E}-01$ & $7.8 \mathrm{E}-01$ & 7.6E-03 & $4.8 \mathrm{E}-02$ & $6.0 \mathrm{E}-01$ & $4.2 \mathrm{E}-02$ & $7.0 \mathrm{E}-01$ & \\
\hline 37 & 2303.7 & 1494335 & 649 & $1.9 \mathrm{E}+00$ & $5.5 \mathrm{E}-01$ & $1.9 \mathrm{E}-01$ & $8.0 \mathrm{E}-02$ & $1.1 \mathrm{E}+00$ & 3.7E-02 & $1.4 \mathrm{E}-01$ & $1.3 \mathrm{E}-03$ & $5.8 \mathrm{E}-01$ & $5.7 \mathrm{E}-02$ & \\
\hline
\end{tabular}

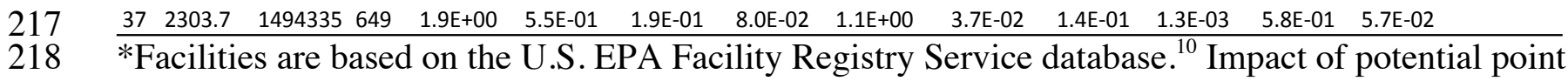

219 sources as a function of distance from sampling locations by assuming exponential decay in the

220 concentration (i.e., Impact $=1 / e^{d}$, where $d=$ hydrological distance, $\mathrm{km}$ ) 


\section{References}

1. Taniyasu, S.; Kannan, K.; So, M. K.; Gulkowska, A.; Sinclair, E.; Okazawa, T.; Yamashita, N., Analysis of fluorotelomer alcohols, fluorotelorner acids, and short- and long-chain perfluorinated acids in water and biota. J. Chromatogr. A 2005, 1093, 89-97.

2. Huset, C. A.; Barlaz, M. A.; Barofsky, D. F.; Field, J. A., Quantitative determination of fluorochemicals in municipal landfill leachates. Chemosphere 2011, 82, 1380-1386.

3. U.S. EPA, Waste Site Cleanup \& Reuse in New England - Bradford Printing \& Finishing https://www3 .epa.gov/region1/removal-sites/BradfordPrintingFinishing.html (accessed Feb 2016). 2012.

4. Hansen, K. J.; Johnson, H. O.; Eldridge, J. S.; Butenhoff, J. L.; Dick, L. A., Quantitative characterization of trace levels of PFOS and PFOA in the Tennessee River. Environ. Sci. Technol. 2002, 36, 1681-1685.

5. Nakayama, S.; Strynar, M. J.; Helfant, L.; Egeghy, P.; Ye, X. B.; Lindstrom, A. B., Perfluorinated compounds in the Cape Fear Drainage Basin in North Carolina. Environ. Sci. Technol. 2007, 41, 5271-5276.

6. Konwick, B. J.; Tomy, G. T.; Ismail, N.; Peterson, J. T.; Fauver, R. J.; Higginbotham, D.; Fisk, A. T., Concentrations and patterns of perfluoroalkyl acids in Georgia, USA surface waters near and distant to a major use source. Environ. Toxicol. Chem. 2008, 27, 2011-2018.

7. $\quad$ Nakayama, S. F.; Strynar, M. J.; Reiner, J. L.; Delinsky, A. D.; Lindstrom, A. B., Determination of Perfluorinated Compounds in the Upper Mississippi River Basin. Environ. Sci. Technol. 2010, 44, 4103-4109.

8. $\quad$ Lasier, P. J.; Washington, J. W.; Hassan, S. M.; Jenkins, T. M., Perfluorinated chemicals in surface waters and sediments from northwest Georgia, USA, and their bioaccumulation in Lumbriculus variegatus. Environ. Toxicol. Chem. 2011, 30, 2194-201.

9. Post, G. B.; Louis, J. B.; Lippincott, R. L.; Procopio, N. A., Occurrence of Perfluorinated Compounds in Raw Water from New Jersey Public Drinking Water Systems. Environ. Sci. Technol. 2013, 47, 13266-13275.

10. US EPA, Facility Registry Service (FRS). http://www.epa.gov/enviro/epa-frs-facilities-state250 single-file-csv-download (accessed Nov 2015). 